\title{
Inflammatory mast cells up-regulate angiogenesis during squamous epithelial carcinogenesis
}

\author{
Lisa M. Coussens, ${ }^{1,6}$ Wilfred W. Raymond, ${ }^{2}$ Gabriele Bergers, ${ }^{1}$ Marion Laig-Webster, ${ }^{2}$ \\ Ole Behrendtsen, ${ }^{3}$ Zena Werb, ${ }^{3}$ George H. Caughey, ${ }^{2,4}$ and Douglas Hanahan ${ }^{1,5}$ \\ ${ }^{1}$ Hormone Research Institute, ${ }^{2}$ Cardiovascular Research Institute, and Departments of ${ }^{3}$ Anatomy, ${ }^{4}$ Medicine, \\ and ${ }^{5}$ Biochemistry and Biophysics, University of California, San Francisco. San Francisco, California 94143-0534 USA
}

\begin{abstract}
Expression of HPV16 early region genes in basal keratinocytes of transgenic mice elicits a multistage pathway to squamous carcinoma. We report that infiltration by mast cells and activation of the matrix metalloproteinase MMP-9/gelatinase B coincides with the angiogenic switch in premalignant lesions. Mast cells infiltrate hyperplasias, dysplasias, and invasive fronts of carcinomas, but not the core of solid tumors, where they degranulate in close apposition to capillaries and epithelial basement membranes, releasing mast-cell-specific serine proteases MCP-4 (chymase) and MCP-6 (tryptase). MCP-6 is shown to be a mitogen for dermal fibroblasts that proliferate in the reactive stroma, whereas MCP-4 can activate progelatinase B and induce hyperplastic skin to become angiogenic in an in vitro bioassay. Notably, premalignant angiogenesis is abated in a mast-cell-deficient $\left(K I T^{W} / K I T W^{W_{V}}\right)$ HPV16 transgenic mouse. The data indicate that neoplastic progression in this model involves exploitation of an inflammatory response to tissue abnormality. Thus, regulation of angiogenesis during squamous carcinogenesis is biphasic: In hyperplasias, dysplasias, and invading cancer fronts, inflammatory mast cells are conscripted to reorganize stromal architecture and hyperactivate angiogenesis; within the cancer core, upregulation of angiogenesis factors in tumor cells apparently renders them self-sufficient at sustaining neovascularization.
\end{abstract}

[Key Words: angiogenesis; cancer; gelatinase B; HPV16; inflammation; mast cells]

Received March 24, 1999; revised version accepted April 20, 1999.

Tumorigenesis is invariably a multistep process (Fearon and Vogelstein 1990; Folkman and Hanahan 1991; Christofori and Hanahan 1994), that involves not only transformed cells but also an assemblage of normal support cells, including stromal fibroblasts, and endothelial cells (Dvorak 1986; Hanahan 1998; Kinzler and Vogelstein 1998). Tumor growth demonstrably depends on angiogenesis, whereby concomitant increases in the tumor vasculature supply nutrients and oxygen to the expanding neoplastic mass (Folkman 1990).

The skin is composed of an avascular epidermal compartment and a subjacent vascularized dermis. Whereas the skin vasculature is typically quiescent (Detmar 1996), it maintains a capability to initiate transitory neovascular responses to diverse epithelial stimuli, e.g., pathogen assault and wounding. The skin microenvironment likely facilitates angiogenic responses; among its salient characteristics is the propensity for rapid inflammatory responses to abnormal tissue conditions, resulting in increased blood supply, increased vascular permeability, and extravasation of diverse cytokine-producing

${ }^{6}$ Corresponding author.

E-MAIL: coussens@cc.ucsf.edu; FAX (415) 502-6779. leukocytes, e.g., macrophages, lymphocytes, and mast cells (for review, see Roitt et al. 1989), seeking to resolve the abnormality.

Mast cells (MCs) play an important role in acute inflammation owing to their release of stored and newly synthesized inflammatory mediators following activation (Yong 1997). MC density within skin connective tissue correlates with blood vessel density (Eady et al. 1979), and activation and degranulation of MCs is associated with connective tissue degradation around sites of neovascularization (Dabbous et al. 1986). As neovascularization of otherwise quiescent tissues, such as skin, involves the action of angiogenic growth factors and the localized proteolytic modification of the extracellular matrix (ECM), MCs are implicated as accessory cells for angiogenesis (Meininger 1995; Yong 1997).

We have investigated mechanisms regulating angiogenesis in a mouse model of epithelial carcinogenesis wherein the early region genes of human papillomavirus type 16 (HPV16) are expressed under the control of the keratin 14 (K14) promoter/enhancer (Arbeit et al. 1994). In this skin cancer model, mice are born phenotypically normal; by 1 month of age mice develop epidermal hyperplasia with $100 \%$ penetrance, which advances fo- 
cally into angiogenic dysplasias between 3 and 6 months. By one year, $50 \%$ of the mice develop invasive squamous cell carcinomas (SCC) (Coussens et al. 1996). Characteristically, cancers appear on the ears and upper trunk. We have determined previously that neoplastic progression in this model is accompanied by up-regulation of genes encoding several pro-angiogenic growth factors (Arbeit et al. 1996), implicating these molecules in tumor angiogenesis in the skin. We now present evidence that inflammatory mast cells are involved in activating premalignant neovascularization in the skin, and propose functional roles for $\mathrm{MC}$-specific proteases in angiogenesis and stromal remodeling in this transgenic mouse model of epithelial carcinogenesis.

\section{Results}

Premalignant dysplasias are characterized by alterations in vascular architecture

In the skin of K14-HPV16 transgenic mice (Smith-McCune et al. 1997), as in human cervical carcinogenesis (Smith-McCune and Weidner 1994; Smith-McCune et al. 1997), neoplastic progression involves an early increase in capillary density first evident subjacent to hyperplastic epithelium. We now report that dramatic changes in dermal capillary location, density, and architecture accompany both premalignant and malignant progression. Normal mouse skin contained infrequent capillaries lo- cated deep within the dermis as visualized by immunolocalization of platelet endothelial cell (EC) adhesion molecule (PECAM-1/CD31), an endothelial cell-specific marker (DeLisser et al. 1994) (Fig. 1A). Hyperplastic lesions showed a modest increase in the density and dilation of capillaries that remain distal to the neoplastic epidermis (Fig. 1B). Dysplastic lesions contained dilated and enlarged capillaries that are increased in number, and localized proximal to the epithelial basement membrane (Fig. 1C). This vascular pattern is indicative of an angiogenic switch from vascular quiescence to modest neovascularization in early low-grade lesions (hyperplasias), followed by a striking upregulation of angiogenesis in high-grade lesions (dysplasias). The core of SCCs, both well differentiated (WDSC; Fig. 1D) and moderately to poorly differentiated (M-PDSC; Fig. 1E), as well as the invasive fronts of the tumors (Fig. 1F), were likewise well vascularized, containing a chaotic array of small and dilated capillary webs.

\section{Stromal infiltration of mast cells accompanies activation of angiogenesis and progression to dysplasia}

Based on clues revealed by whole-mount visualization of the vasculature, we asked whether MCs were associated with the distinctive stages of carcinogenesis by utilizing chloroacetate esterase (CAE) histochemistry on paraffinembedded sections of staged neoplastic skin (Fig. 2). CAE detects the presence of chymotrypsin-like serine ester-
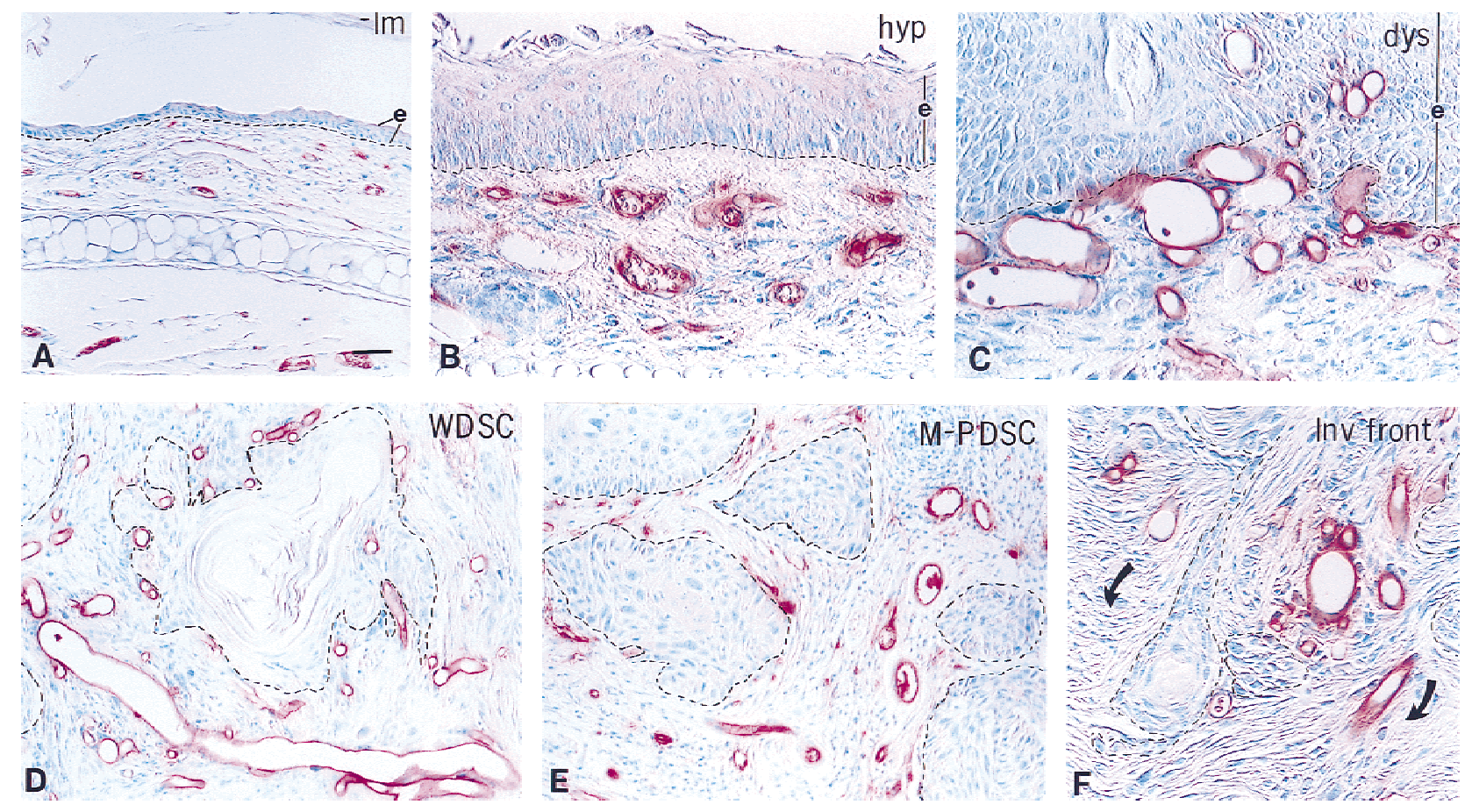

Figure 1. Altered morphology and architecture of capillaries during premalignant neovascularization. Immunohistochemical staining of 5- $\mu \mathrm{m}$ paraffin-embedded tissue sections for CD31 expressed on capillary endothelial cells (red staining) counterstained with methyl green in $(A)$ normal nontransgenic (-lm) ear skin, $(B)$ hyperplastic (hyp) ear skin, $(C)$ dysplastic (dys) ear skin, $(D)$ ear WDSC, $(E)$ truncal M-PDSC center, and $(F)$ the invasive front (Inv front) of a truncal M-PDSC with arrows indicating direction of tumor expansion. (Dashed line) Epidermal-dermal interface or location of skin basement membrane zone; (e) epidermis. Bar, $44.6 \mu \mathrm{m}(A-F)$. 

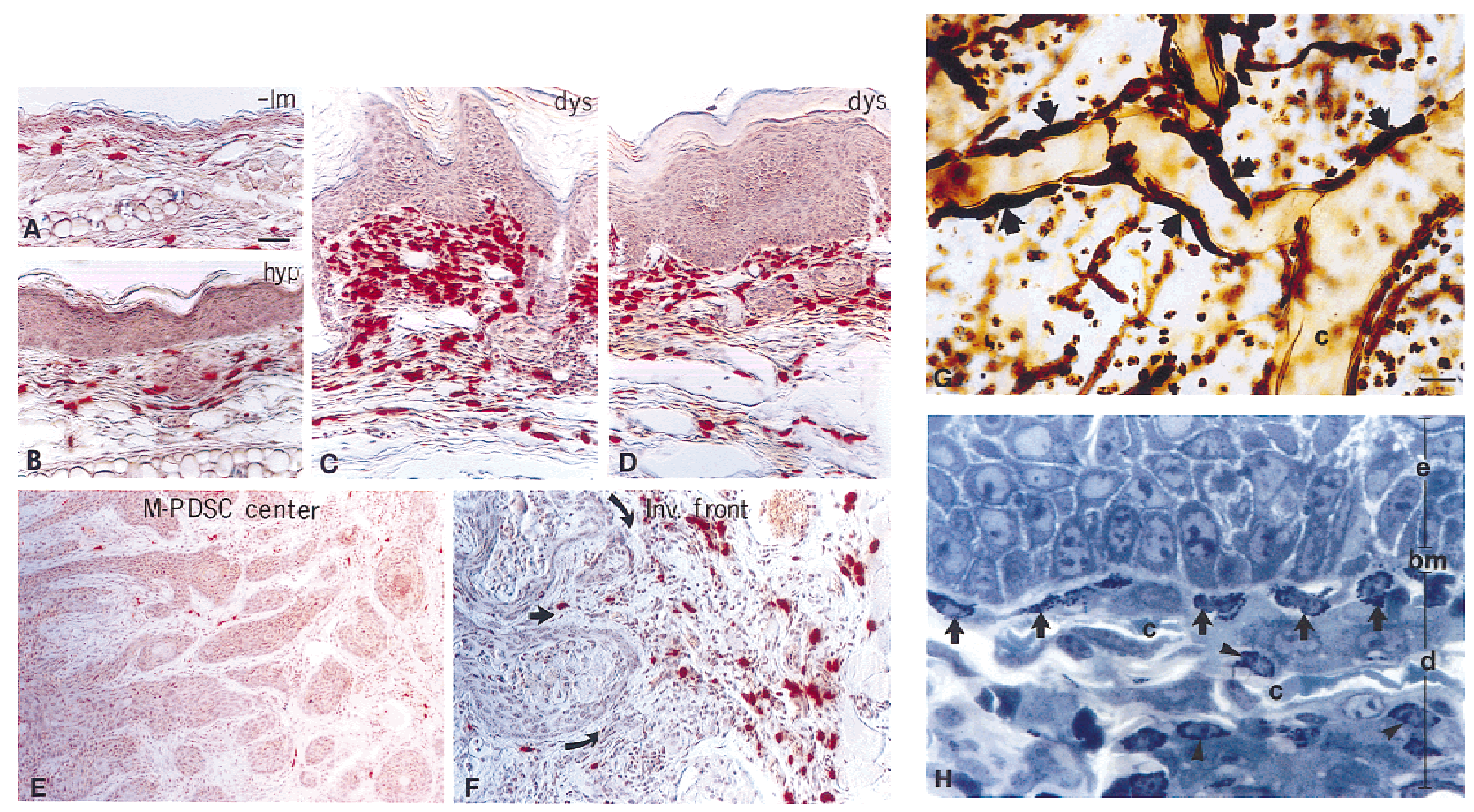

Figure 2. Mast cell infiltration during activation of angiogenesis. Chloroacetate esterase histochemistry (red staining) on 5- $\mu \mathrm{m}$ paraffin-embedded tissue sections counterstained with hematoxylin (blue) identifies location of infiltrating MCs during neoplastic progression in $(A)$ nontransgenic litter mate $(-1 \mathrm{~m})$ ear skin, $(B)$ hyperplastic (hyp) ear skin, $(C$ and $D)$ dysplastic (dys) ear skin, $(E)$ the center of a chest M-PDSC, $(F)$ and at the invading front of a truncal M-PDSC. Arrows indicate direction of tumor expansion. (G) Whole-mount microscopy of lectin-perfused transgenic mouse with dysplastic truncal lesions. Darkly stained mast cells (arrows) appear to adhere directly to basement membranes surrounding the dermal capillaries (c) in angiogenic dysplasias. $(H)$ Metachromatic granules in MCs stained with toluidine blue. Degranulating mast cells (arrows) present within a dysplastic lesion are juxtaposed tightly to skin basement membrane (bm) and dermal capillaries (c, arrowhead). (d) Dermis, (e) epidermis. Bar, $44.6 \mu \mathrm{m}(A-D, F) ; 89 \mu \mathrm{m}(E) ; 19.7$ $\mu \mathrm{m}(G) ; 12.9 \mu \mathrm{m}(H)$.

ases (chymases) present within connective tissue MCs (Leder 1979; Caughey et al. 1988). Normal skin contained few MCs distributed within the dermis distal to the epidermal basement membrane (Fig. 2A). MC numbers increased at the hyperplastic stage, and were associated predominately with small blood vessels within dermal stroma (Fig. 2B). With the switch to intense angiogenesis in dysplasias, MC density increased markedly in the dermal connective tissue in both early (3-monthold) and late (6-month-old) angiogenic lesions (Fig. 2C,D, respectively). In contrast to the angiogenic dysplasias, tumor stroma within M-PDSCs was essentially devoid of MCs (Fig. 2E). However, the stroma around invading fronts of the tumors contained abundant MCs, most frequently abutting capillaries (Fig. 2F). MCs were never observed within the epithelial compartment at any stage of neoplastic progression.

Exploiting the avidin and toluidine blue binding capabilities of tissue MCs to view their location at high resolution (Befus et al. 1982; Tharp et al. 1985), we saw an intimate association between infiltrating MCs in angiogenic dysplasias with both subendothelial and epithelial basement membranes (Fig. 2, G and H, respectively).

We assessed the possibility that intense MC infiltration of dysplastic lesions was an antibody-mediated re- sponse to chronic bacterial infection of the skin, by treating one cohort of transgenic mice systemically with antibiotics [sulfamethoxole $(60 \mathrm{mg} /$ tablet $)$, trimethoprim $(10 \mathrm{mg} /$ tablet $), 1$ tablet $/ 2$ mice per week], and by breeding a second cohort into the immunodeficient Rag1/null background (Mombaerts et al. 1992). These treatments did not alter influx of MCs into the stroma beneath dysplastic epidermis (data not shown). Thus, the presence of MCs in angiogenic dysplasias does not appear to be a response to activation of the humoral immune system.

\section{Angiogenic dysplasias are highly enriched in mast cell-specific serine proteases}

We next quantified the activities of MC-specific tryptic and chymotryptic serine proteases (tryptases and chymases, respectively) in extracts of tissue from each neoplastic stage with selective solution assays (Fig. 3A). Although chymase-like activity was detectable in normal negative littermate control tissue $[n=2 ; 62.5 \pm 17.5$ nmoles of pNA/min per $\mathrm{mg}$ protein (s.E.M.)] and in hyperplastic tissue $(n=4 ; 39.8 \pm 13.5$ nmoles of pNA $/ \mathrm{min}$ per $\mathrm{mg}$ protein), there was a significant increase in activity in angiogenic dysplasias $(n=6 ; 204 \pm 3.6$ nmoles of $\mathrm{pNA} / \mathrm{min} / \mathrm{mg}$ protein; $P<0.003)$. In addition, angio- 
A

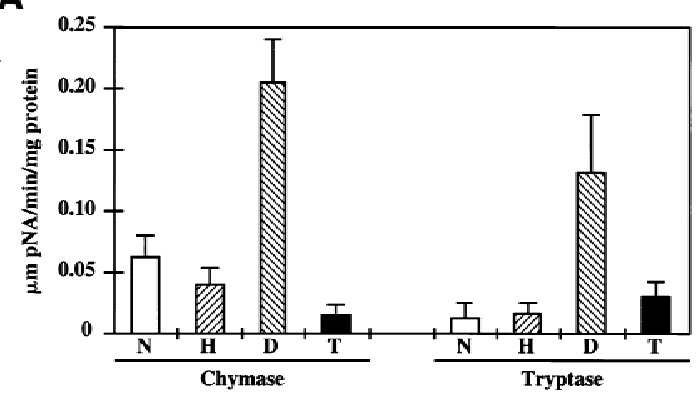

B

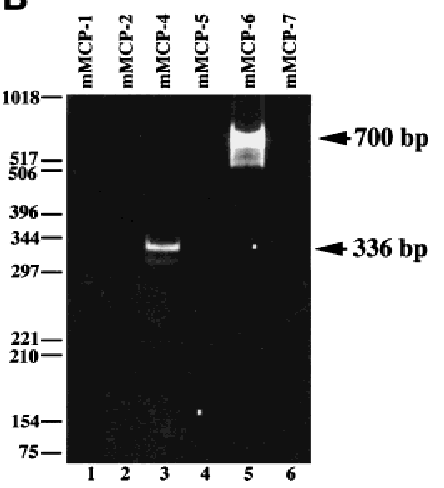

C

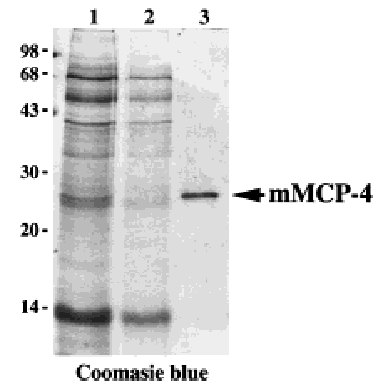

D

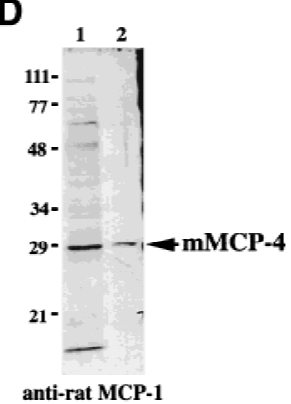

E

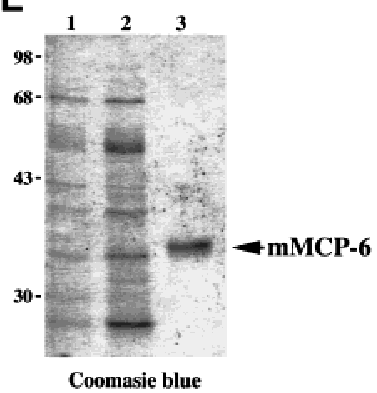

genic dysplasias contained higher levels of chymase-like activity than SCCs $(n=3 ; 15.3 \pm 8.2$ nmoles of pNA/ $\mathrm{min} / \mathrm{mg}$ protein). Chymase-like activity in extracts was completely inhibited by $10 \mu \mathrm{M}$ soybean trypsin inhibitor (SBTI), but not by $100 \mu \mathrm{g} / \mathrm{ml}$ aprotinin, as is characteristic of MC chymases (Caughey 1995).

Similarly, tryptase-like activity was detectable in both normal $(n=2 ; 13 \pm 13$ nmoles of $\mathrm{pNA} / \mathrm{min}$ per $\mathrm{mg}$ protein) and hyperplastic $(n=4 ; 15.7 \pm 10.6$ nmoles of pNA $/$ $\mathrm{min} / \mathrm{mg}$ protein) skin; again, angiogenic dysplasias possessed significantly elevated activity $(n=6 ; 131 \pm 49.3$ nmoles of $\mathrm{pNA} / \mathrm{min}$ per mg protein; $P<0.04)$, compared to the former and to frank carcinomas $(n=3 ; 30 \pm 12.6$ nmoles of $\mathrm{pNA} / \mathrm{min} / \mathrm{mg}$ protein). The tryptase-like activity in extracts was inhibited by $1.5 \mathrm{~mm}$ benzamidine, a general inhibitor of tryptic serine proteases, but not by $10 \%$ mouse plasma (data not shown). Resistance to serine protease inhibitors present in plasma is an idiosyncratic feature of MC tryptases.

MCs in different anatomic locations and in different pathologic conditions selectively express distinct chy-
Figure 3. Chymase and tryptase in neoplastic skin. $(A)$ Chymotryptic and tryptic activity in neoplastic skin. Values represent mean chymase and tryptase activity in ear skin biopsies from negative littermate (N), hyperplastic (H), dysplastic (D), and tumor $(\mathrm{T})$ solubilized by extraction at high ionic strength, normalized to the amount of protein in extracts \pm S.E.M.); 5 - $\mu$ l each of tissue sample were incubated with $1 \mathrm{~mm}$ chymotryptic or tryptic substrate. The change in absorbance at $410 \mathrm{~nm}$ at $37^{\circ} \mathrm{C}$ is shown where units indicate umoles of substrate cleaved/min per mg protein. (B) RT-PCR analysis for all mMCPs in dysplastic ear mRNA. Sizes shown indicate base pairs. All primer pairs were tested for specific priming of control RNA. (C) SDS-PAGE of mMCP-4 purification from K14HPV16 mouse ears. Samples were reduced with dithiothreitol and visualized with Coomassie brilliant blue. (Lane 1), $2 \mathrm{M}$ $\mathrm{NaCl}$ extract of K14-HPV mouse ears (5 $\mu \mathrm{g}$ of protein); (lane 2) $2 \mathrm{M} \mathrm{NaCl}$ extract SBTI-agarose unbound fraction (1 $\mu \mathrm{g}$ of protein); (lane 3), $5 \mu \mathrm{g}$ of pure $\mathrm{mMCP}-4$, SBTI-agarose acid eluate. (D) Anti-rat MCP-1 IgG reacts specifically with mMCP-4. (Lane 1) Crude high-salt extract of ears (2 $\mu 1)$; (lane 2), $2.5 \mathrm{ng}$ of purified mMCP-4 from SBTI-agarose acid eluate. (E) SDSPAGE of mMCP-6 purification from K14-HPV16 mouse ears. Samples were reduced with dithiothreitol and visualized with Coomassie brilliant blue. (Lane 1) Unbound fraction from $p$ aminobenzamidine-agarose chromatography, $2 \mu 1$; (lane 2), 2 $\mathrm{M} \mathrm{NaCl}$ extract, unbound fraction, $2 \mu 1$; (lane 3) MMCP-6 peak $(240 \mathrm{ng})$ from heparin-HPLC $\mathrm{NaCl}$ gradient elution. Molecular masses are shown in $\mathrm{kD}$.

mase transcripts [mouse mast cell protease (mMCP) 1 , $-2,-4$ and/or -5 ] and tryptase transcripts (mMCP-6 and/ or -7) (Reynolds et al. 1990; Stevens et al. 1994). We detected mRNA representing only mMCP-4, a $\beta$-chymase, and mMCP-6, a tryptase, by RT-PCR analysis of RNA isolated from dysplastic ear skin (Fig. 3B). We confirmed the presence of their encoded gene products by immunoblot analysis of neoplastic skin lysates; an $~ 28$ $\mathrm{kD}$ mMCP-4 was detected with affinity-purified anti-rat MCP-1 IgG (rat MCP-1 is the ortholog of mMCP-4; Caughey 1995) and an $\sim 34 \mathrm{kD}$ mMCP-6 was detected with affinity-purified anti-mMCP-6 IgG (Ghildyal et al. 1996) (data not shown).

The chymase purified from angiogenic dysplasias represented $99 \%$ of the chymotryptic activity loaded onto an SBTI-agarose column. It had a specific activity of 5.5umole of succinyl-L-Ala-Ala-Pro-Phe-4-nitroanilide hydrolyzed/min per $\mathrm{mg}$, migrated as a predominant band at $\sim 28 \mathrm{kD}$ by SDS-PAGE (Fig. 3C), and reacted with anti-rat MCP-1 IgG in immunoblotting (Fig. 3D). The aminoterminal sequence of the purified chymase was IIG- 
GVESRP, which is identical to the published amino acid sequence of mMCP-4 (Huang et al. 1991). Purified mMCP-4 was inhibited completely by SBTI in a 1:100 enzyme-to-inhibitor molar ratio, but inhibited only weakly by aprotinin in a 500-fold molar excess (data not shown).

mMCP-6 was purified from dysplastic K14-HPV16 transgenic mouse ears by high-salt buffer extraction followed by $p$-amino benzamidine and heparin affinity chromatography. The purified tryptase migrated as a single protein band at $\sim 34 \mathrm{kD}$ (Fig. 3E), and immunoblotted with anti-mMCP-6 antibody (data not shown). The amino-terminal sequence was IVGGHEASES, identical to mMCP-6 (Reynolds et al. 1991) and distinct from the other mouse tryptase, mMCP-7. The specific activity of purified mMCP-6 was 56 mole of tosyl-Gly-Pro-Lys4-nitroanilide hydrolyzed/min per $\mathrm{mg}$. This activity represented $99 \%$ of the tryptic activity present in the highsalt buffer loaded onto the benzamidine-agarose column (data not shown). MMCP-6 was inhibited by bis (5-amidino-2-benzimidazoyl) methane (BABIM) at a 1:500 molar ratio, a potent inhibitor of mast cell tryptases (Caughey et al. 1993), but was resistant to inhibition by aprotinin, at a 1:75 enzyme-to-inhibitor molar ratio.

\section{Mouse MCP-6 is a mitogen for dermal fibroblasts}

We observed that the cellularity of dermal fibroblasts and the deposition of collagen into the ECM, as demonstrated by Masson's trichrome staining (data not shown), increased incrementally during early neoplastic progression. This is notable, as stromal fibroblasts in skin, much like ECs, are typically quiescent (Gregoire and Lieubeau 1995). In wound healing and neoplastic situations, proliferating fibroblasts are the source of newly synthesized type I procollagen and are responsible for desmoplastic phenotypes (Vuorio and de Crombrugghe 1990; Gregoire and Lieubeau 1995). Tryptase is a mitogen (Hartmann et al. 1992) and potent stimulator of type $\alpha 1(I)$ procollagen mRNA synthesis (Cairns and Wells 1997; Gruber et al. 1997) in human fibroblasts in vitro. These activities of tryptase may be mediated through interaction with protease activated receptor-2 (PAR-2) present on fibroblast plasma membranes (Molino et al. 1997; Schechter et al. 1998).

Accordingly, we tested the ability of mMCP-6 tryptase and mMCP-4 chymase to stimulate DNA synthesis of quiescent serum-deprived subconfluent primary murine dermal fibroblasts (PMDFs) and quiescent human umbilical vein endothelial cells (HUVECs), in the absence of exogenous growth factors. MMCP-6 stimulated fibroblast DNA synthesis selectively in a concentrationdependent manner yet did not affect proliferation of HUVECs. (Fig. 4A,B). In contrast, mMCP-4 did not stimulate DNA synthesis in either cell population at any concentration tested (Fig. 4A,B). These results demonstrate that mMCP-6 tryptase has cell-type-specific mitogenic potency.

In vivo, we observed that normal skin exhibited patchy expression of type $\alpha 1(I)$ procollagen mRNA in stroma adjacent to capillaries (Fig. 4C), whereas mRNA expression was up-regulated incrementally in hyperplastic lesions adjacent to capillaries and subjacent to epithelium (Fig. 4D). In angiogenic dysplasias heavily infiltrated with MCs, type $\alpha 1$ (I) procollagen mRNA was expressed widely in stroma (Fig. 4E), consistent with high levels of tryptase, increased cellularity of dermal fibroblasts, and increased deposition of collagen.

\section{MMCP-4 induces ECM remodeling and angiogenesis by direct and indirect mechanisms}

The cell proliferation assay pointed to a role for tryptase in activating quiescent fibroblasts to become a proliferative component of the reactive neoplastic stroma; that same assay revealed no mitogenic activity of chymase on fibroblasts or endothelial cells. Therefore, we asked whether chymase contributed by altering tissue microenvironment in some other way. Interestingly, canine and human $\mathrm{MC} \alpha$-chymases are known to activate the latent extracellular protease progelatinase B (proMMP-9) (Fang et al. 1996 1997). Gelatinase B is a member of the matrix metalloproteinase (MMP) family and is involved in both ECM remodeling (Coussens and Werb 1996) and regulation of angiogenesis (Vu et al. 1998).

We hypothesized, therefore, that $\mathrm{mMCP}-4$ contributed to activation of angiogenesis by inducing ECM remodeling through the activation of progelatinase B. To address this, we first assessed the relative activity of gelatinase B in tissue lysates representing distinct neoplastic stages utilizing gelatin-substrate zymography (Fig 5A). Progelatinase B was not detectable in normal skin, but was up-regulated incrementally in hyperplastic, dysplastic, and tumor tissue; however, active gelatinase B appeared only in the dysplastic and tumor lysates. In addition, this assay revealed the activity profile of another MMP family member, namely pro- and active gelatinase A (MMP-2), whose activity changed only modestly in the different neoplastic stages. The appearance of activated gelatinase B in dysplastic lesions correlated with dramatic MC infiltration and elevated levels of mMCP-4 chymase activity.

To test if mMCP-4 could activate progelatinase $\mathrm{B}$, similar to canine or human $\alpha$-chymases, lysates from hyperplastic skin /containing predominantly the proform of gelatinase B) were incubated with purified mMCP-4 prior to substrate zymography. Incubation of the lysates with mMCP-4 led to a dramatic increase in the amount of activated gelatinase B, whereas neither the pro nor active forms of gelatinase A were changed (Fig. 5B). Addition of ecotin (an inhibitor of mMCP-4 but not urokinase) abolished $\mathrm{mMCP}$-4-induced activation of gelatinase B completely, whereas $1 \mathrm{~mm}$ amiloride (an inhibitor of urokinase) had no effect (data not shown). Furthermore, immunolocalization of mMCP-4 (red staining; Fig. 5C,D) and gelatinase B (blue staining; Fig. 5E) in dysplastic tissue sections revealed colocalization of both enzymes proximal to epithelial and subendothelial basement membranes as demonstrated by immunolocalization of laminin- $\beta 1$ (brown staining, Fig. $5 \mathrm{C}, \mathrm{D})$. Thus, 
A

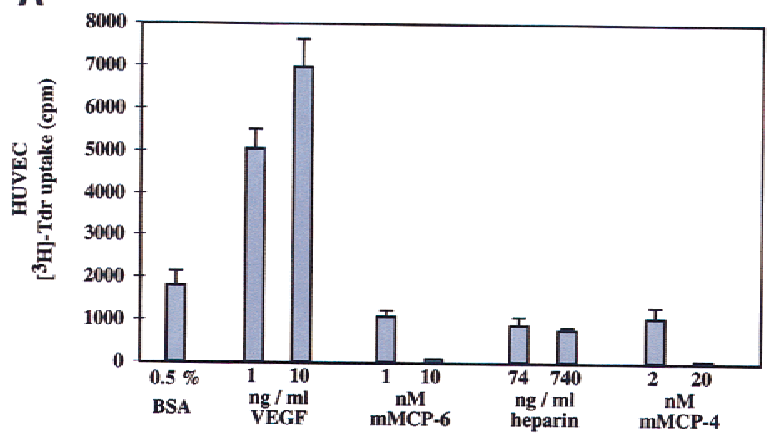

B

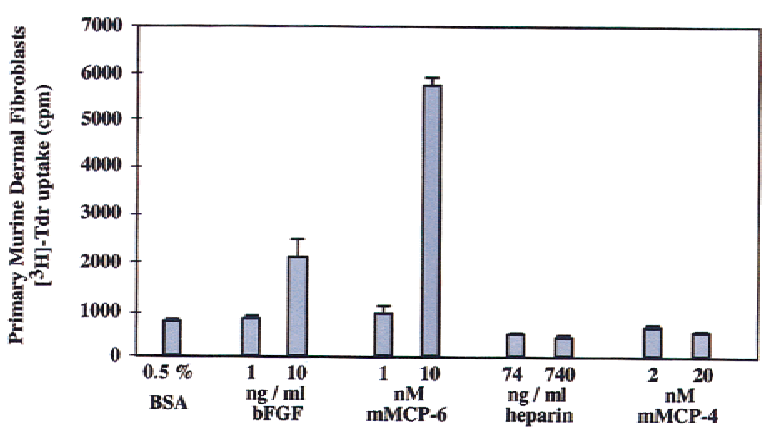

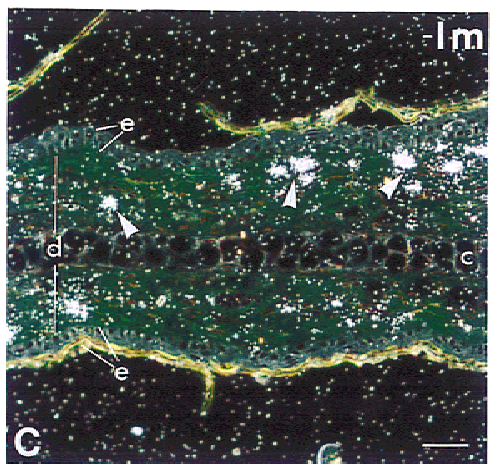
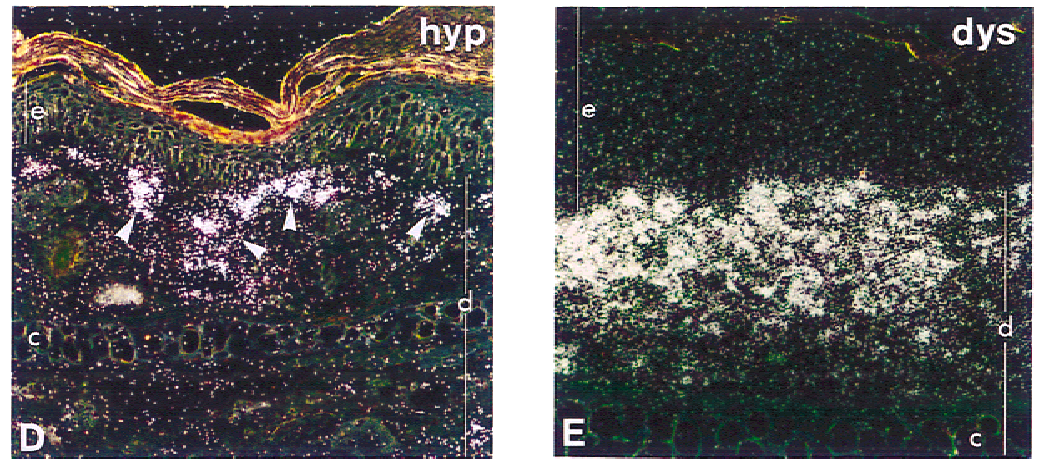

Figure 4. Effects of tryptase on skin fibroblasts. Effect of MCPs on HUVEC proliferation $(A)$ and on PMDF proliferation $(B)$. Agonists were added to subconfluent, serum-deprived cultures (VEGF, 1 and $10 \mathrm{ng} / \mathrm{ml}$; bFGF, 1 and $10 \mathrm{ng} / \mathrm{ml}$; mMCP-6, 1 and $10 \mathrm{nM}$; mMCP-4, 2 and $20 \mathrm{~nm}$; heparin at 74 and $740 \mathrm{ng} / \mathrm{ml}$ ) for $16 \mathrm{hr}$. $\left[{ }^{3} \mathrm{H}\right]$ Thymidine incorporation was then determined. Results shown indicate mean values ( \pm S.E.M.; $n=3)$. $(C-E)$ Dark-field photographs of ear-tissue sections from $(C)$ negative litter mate $(-\operatorname{lm})$ normal skin, $(D)$ hyperplastic (hyp) skin, and $(E)$ dysplastic (dys) skin hybridized with a $(\alpha 1)$ I procollagen antisense mRNA probe. Arrows point to procollagen expressing cells within the stroma. (e) Epidermis; (d) dermis, (c) central ear cartilage. Bar, $44.6 \mu \mathrm{m}(C-E)$.

mMCP-4 colocalizes with and induces activation of progelatinase $\mathrm{B}$, but not progelatinase $\mathrm{A}$, in early neoplastic tissue.

We next asked if mMCP-4 chymase, mMCP-6 tryptase, or gelatinase B could convert an otherwise nonangiogenic tissue to an angiogenic one utilizing an in vitro angiogenesis bioassay (Fig. 6). Hyperplastic ear skin from 1 -month-old transgenic mice was incubated in medium alone or medium containing mMCP-4, mMCP-6, or gelatinase B. Subsequently, the hyperplastic skin was embedded into a collagen gel alone, or a collagen gel containing randomly dispersed bovine capillary endothelial cells (BCEs). Hyperplastic skin pieces, both control and protease-treated, were placed into collagen gels lacking BCEs. They showed negligible cell emigration from biopsies (data not shown). BCEs remained randomly distributed around untreated hyperplastic skin (Fig. 6A). Treatment of skin with mMCP-6 also yielded no response (Fig. 6B), even though human tryptase is a known EC morphogen (Blair et al. 1997). In contrast, mMCP-4treated skin induced a dramatic response of the BCEs, with radial alignment, proliferation, migration, and tube formation toward the dermal surface of the skin pieces with no evidence of migration or tube formation in the direction of the epidermis (Fig. 6C,D). Gelatinase B-treated hyperplastic skin showed a similar response to that observed with mMCP-4 (data not shown). Neither mMCP-4 nor gelatinase B added directly to BCEs in the collagen gel induced a response (data not shown), indicating that these activities were caused directly by release of sequestered activity from the skin pieces. Thus, both $\mathrm{mMCP}-4$ and gelatinase B induce ECM remodeling of hyperplastic tissue directly leading to release of sequestered angiogenic activity.

\section{MC deficiency abates premalignant progression}

Our data suggest that MC-derived factors, including chymase and tryptase, are involved in the early events of neoplastic progression, e.g., fibroblast activation, ECM remodeling, and activation of angiogenesis. To test this hypothesis, we sought to take advantage of mice that were genetically MC deficient. The receptor tyrosine kinase c-Kit, is encoded by the white spotting (W) locus on mouse chromosome 5 (Chabot et al. 1988). Complete loss of c-Kit function is lethal; however, mice carrying $K I T^{W}$ mutations $\left(W 37, W^{v}, W 41\right.$, and $W$ ) are viable to varying degrees, but manifest pleiotropic developmental defects, including sterility, coat color abnormalities, severe macrocytic anemia, and mast-cell deficiency (Bernstein et al. 1990; Nocka et al. 1990). The tissues of adult $\mathrm{WBB}_{1} \mathrm{KIT}_{1} / K I T^{W_{V}}$ mice contain $<1 \%$ the number of 

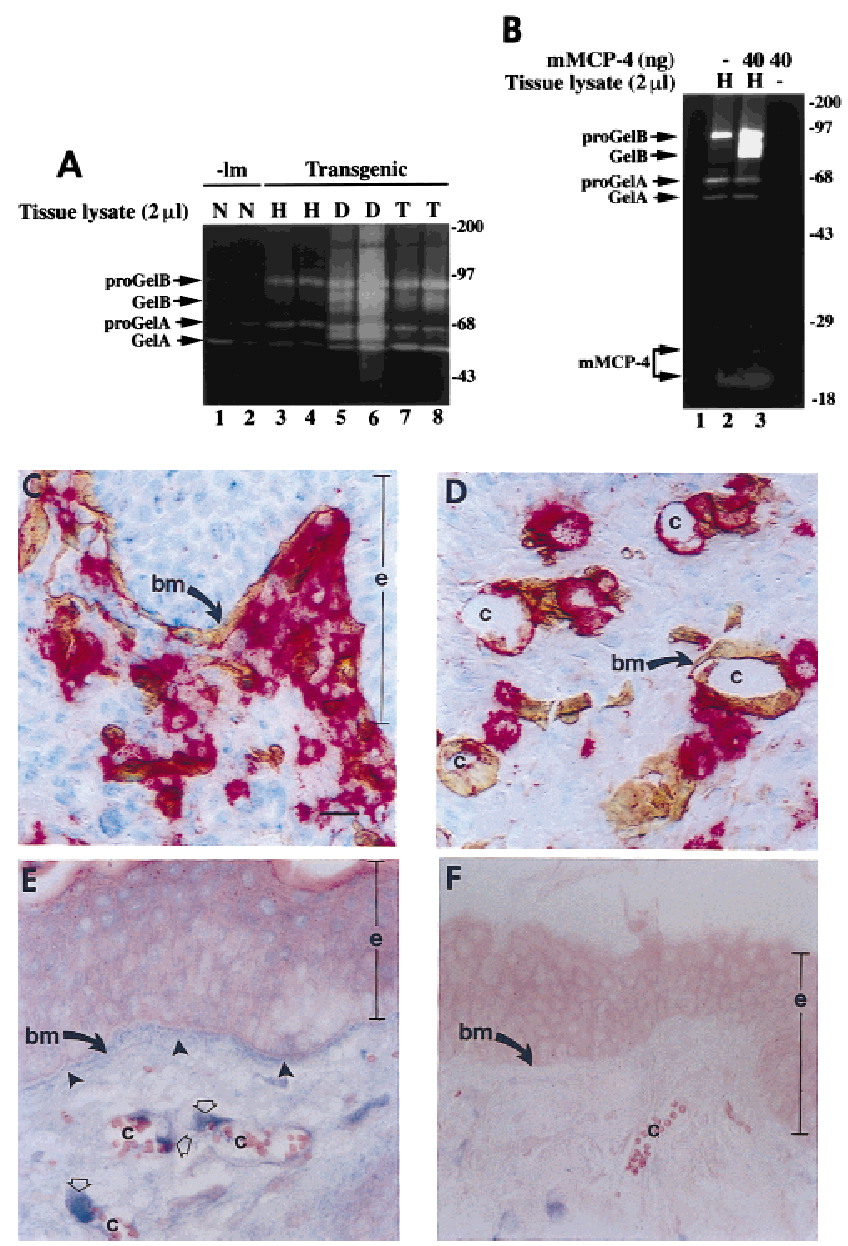

Figure 5. Effect of $\mathrm{mMCP}-4$ on progelatinase B present in hyperplastic tissue and localization of $\mathrm{mMCP}-4$ and gelatinase $\mathrm{B}$ in vivo. (A) Gelatinolytic activity in tissue lysates $(2 \mu \mathrm{l})$ from normal $(\mathrm{N})$, hyperplastic $(\mathrm{H})$, dysplastic $(\mathrm{D})$ and carcinoma $(\mathrm{T})$ biopsies. Incubation of gelatin zymograms with 1,10 phenanthroline (an inhibitor of MMPs), but not PMSF (an inhibitor of serine proteases) following electrophoresis abolished the $68,72,80$, and $90-\mathrm{kD}$ bands completely (data not shown). (B) In vitro reconstitution of gelatinase B activity. Two microliters of hyperplastic $(\mathrm{H})$ lysate alone or $2 \mu \mathrm{l}$ of hyperplastic lysate incubated for $30 \mathrm{~min}$ at $37^{\circ} \mathrm{C}$ with $40 \mathrm{ng}$ of purified mMCP-4. Molecular masses are shown in $\mathrm{kD}$. $(C-D)$ Immunolocalization of mMCP-4 (red staining) and laminin (brown staining) at basement membranes (bm, arrows) adjacent to epithelium (e) and capillaries (c) in dysplastic skin. (E) Immunolocalization of gelatinase B (blue staining) in dysplastic skin localizes to basement membranes (bm) adjacent to epithelium (e, closed arrows) and around capillaries (c, open arrows) in dermis. (F) Control for nonspecific binding using a control rabbit IgG; background staining was negligible. Bar, $44.6 \mu \mathrm{m}(C-F)$.

MCs compared to their normal $(+/+)$ littermates (Kitamura et al. 1978). Thus, we attempted to generate K14HPV16 KIT ${ }^{W} / K I T^{W_{V}}$ mice to assess the importance of MCs as extrinsic potentiators of early neoplastic progression.

Because $\mathrm{WBB} \mathrm{F}_{1} K I T^{W} / K I T^{W_{V}}$ mice are sterile (Nocka et al. 1990), and because neoplastic progression in K14-
HPV16 is only permissive in $\mathrm{FVB} / \mathrm{n}$ /Coussens et al. 1996), we first crossed both $K I T^{W} /+(\mathrm{WB} / \mathrm{ReJ})$ and $K I T^{W_{V}} /+(\mathrm{C} 57 \mathrm{BL} / 6 \mathrm{~J})$ alleles into $\mathrm{FVB} / \mathrm{n}$ for four generations. At the fourth generation, we intercrossed each $W$ allele with K14-HPV16; genotypes of the expected Mendelian ratios were obtained. To obtain K14-HPV16 $K I T^{W} / K I T^{W_{V}}$ genotypes, we crossed HPV16 $\mathrm{KIT}^{W} /+$ with $K I T^{W_{V}} /+$, and HPV16 KIT ${ }^{W_{V}} /+$ with $K I T^{W} /+$, generating 104 litters and 712 pups. The expected simultaneous transmission frequency of all three desired loci is $12.5 \%$. Thus, of the 712 live pups, 179 should have been $K I T^{W} / K I T^{W_{V}}$ and of those, 89 would be predicted to be K14-HPV16 KIT ${ }^{W} / K I T^{W_{V}}$. Instead, one K14-HPV16 $K I T^{W} / K I T^{W_{V}}$ mouse and no $K I T^{W} / K I T^{W_{V}}$ mice were born. When we analyzed litter size of the $K I T^{W} /+$ with $K I T^{W_{V}} /+$ crosses, we realized that on average, litters contained $25 \%$ fewer live births $[6.85 \pm 2.94 P<0.0001$.]

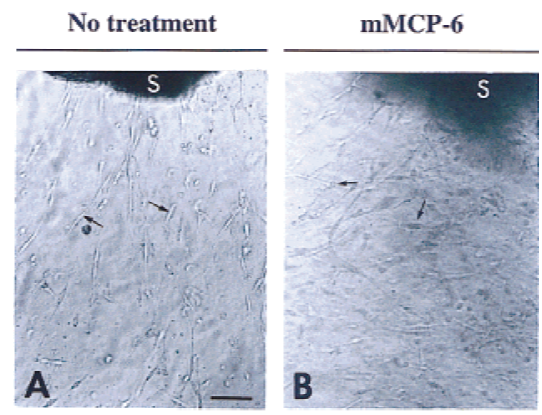

mMCP-4

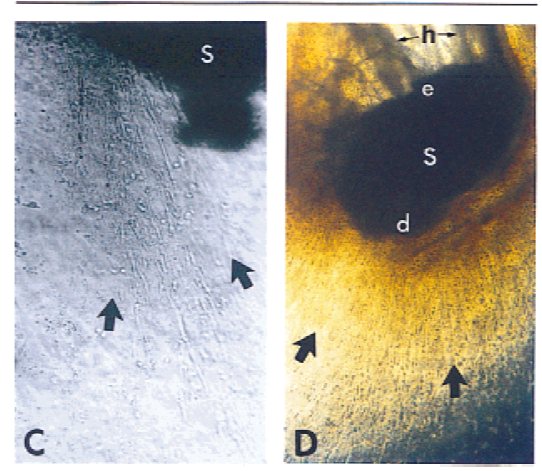

Figure 6. Effect of mMCP-4 on sequestered angiogenic activity in premalignant tissue. Hyperplastic ear skin (S) from a 1-month old K14-HPV16 mouse was incubated for $48 \mathrm{hr}$ in the presence or absence of enzymes at $37^{\circ} \mathrm{C}$ followed by implantation into a collagen gel with EC coculture. Cultures were maintained for 3 weeks, with photographs of tube ingrowths taken after 12 days of coculture. $(A)$ untreated ear skin implanted into EC-collagen gel; $(B)$ mMCP-6-treated (10 nM) ear skin implanted into ECcollagen gel; $(C$ and $D)$ mMCP-4-treated $(20 \mathrm{nM})$ ear skin implanted into EC-collagen gel showing an angiogenic response with extensive EC tube formation. Lower magnification $(D)$ shows the polarized direction of tubular structures towards the dermal (d) surface, as opposed to the epidermal (e) surface of the skin. Small arrows $(A$ and $B)$ indicate the more-or-less random growth of ECs, whereas thick arrows $(C$ and $D)$ indicate radially aligned tubules growing toward the skin piece. (h) Hair. Bar: 58 $\mu \mathrm{m}(A-C) ; 116 \mu \mathrm{m}(D)$. 
as compared to K14-HPV16 with $\mathrm{FVB} / \mathrm{n}$ crosses $[8.79 \pm 3.31$ ( \pm S.D.),$n=80$ litters, 703 mice), leading us to conclude that in the FVB/n background, $K I T^{W} / K I T^{W_{V}}$ produces a near-lethal phenotype. Hence, much like with many targeted gene knockouts, genetic background has a profound effect on viability.

We analyzed the neoplastic phenotype in the K14HPV16 KIT ${ }^{W} / K I T^{W V}$ mouse at 2 months of age (shortly before it died) in comparison to MC-proficient littermates $\left(\mathrm{KIT}^{+} / \mathrm{KIT}^{+}\right.$and K14-HPV16 KIT ${ }^{+} / \mathrm{KIT}^{+}$; Fig. 7). At this point in neoplastic progression, the hyperplastic phenotype in K14-HPV16 mice is $100 \%$ penetrant $(n=380)$, and is characterized by a thickened epidermis with underlying dermal MC infiltration (CAE, red staining; Fig. 7B), hyperproliferation of keratinocytes (Ki-67, brown staining; Fig. 7E), and altered vascular architecture including increased vascular density and dilation (CD-31, brown staining; Fig. 7H). In the K14-HPV16 $K I T^{W} / K I T^{W_{V}}$ mouse, MCs were absent from the dermis (Fig. 7C). Keratinocyte proliferation, as measured by immunoreactivity of Ki-67, although enhanced [Fig. 7F, brown staining; $35 \% \pm 2.8$ (s.E.M.), $n=10,20 \times$ fields] compared to skin of negative littermates [Fig. 7D, brown staining; $12 \% \pm 1.2$ (s.E.M.), $n=10,20 \times$ fields/mouse, 3 mice], was markedly decreased compared to K14-HPV16
$\mathrm{KIT}^{+} / \mathrm{KIT}^{+}$littermates (Fig. 7E, brown staining; $48 \% \pm 1.6 \%$ (s.E.M.), $n=10,20 \times$ fields/mouse, 8 mice]. Likewise, dermal vasculature in the K14-HPV16 $\mathrm{KIT}^{W} /$ $K I T^{W_{V}}$ skin (Fig. 7I) was more similar to quiescent vasculature typical of normal skin (Fig. 7G) than to that observed in angiogenic skin (Fig. $7 \mathrm{H})$, with infrequent, nondilated vessels found distal to the epidermal basement membrane. Thus, by three different criteria (epidermal thickness, keratinocyte proliferation, and vascularization) the absence of MCs functionally compromises early neoplastic progression.

\section{Discussion}

Inflammation is a protective reaction elicited by the host in response to infection, injury, or tissue damage. Under normal physiologic circumstances, this response serves to destroy pathogens, and initiate repair. Inflammatory reactions are also observed commonly in human neoplasia (Wernert 1997; Ohtani 1998). Thus, several parallels exist between the generation of tumor stroma and healing of wounds, supporting the concept that tumor stroma is, in part, wound healing gone awry (Dvorak 1986). In this report, we demonstrate that an inflammatory reaction, characterized by stromal infiltration of

\section{$(-) \mathbf{L M}$}
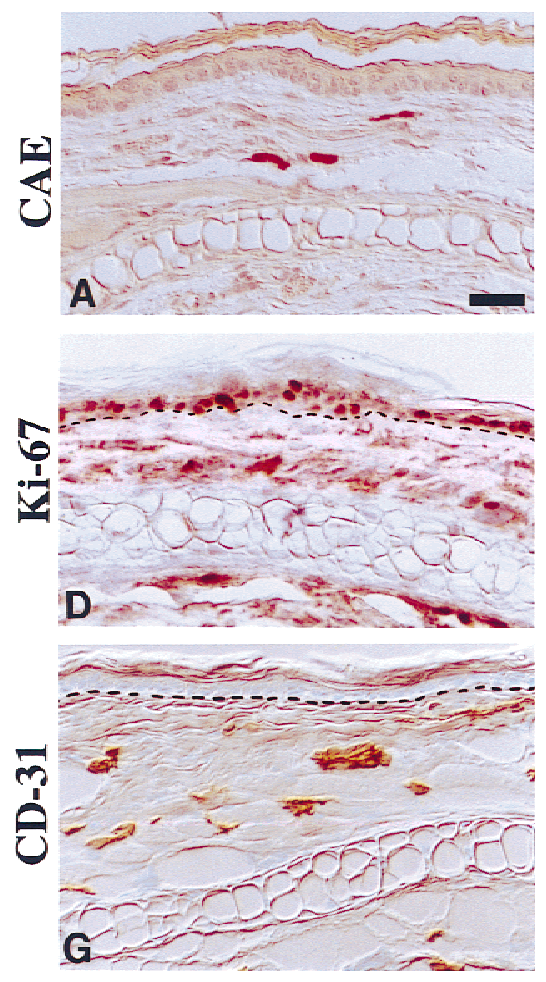
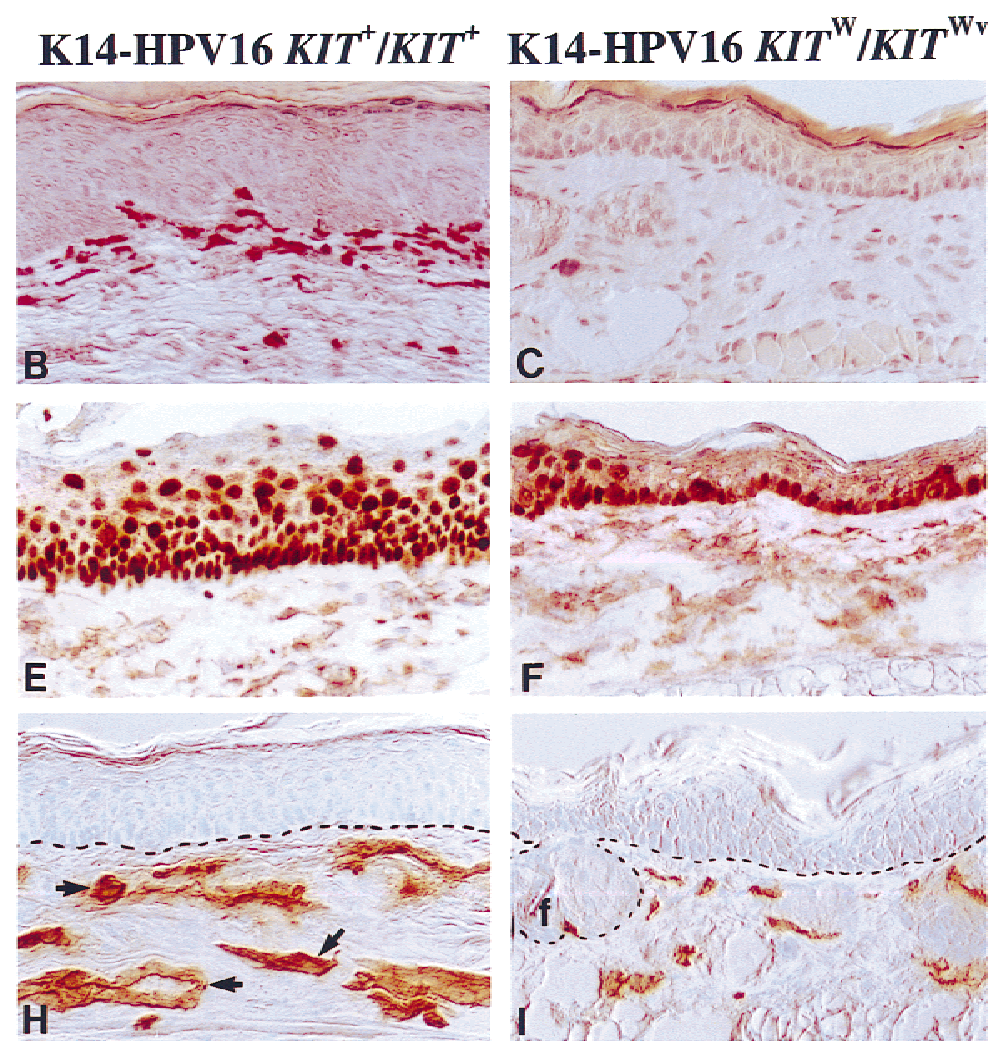

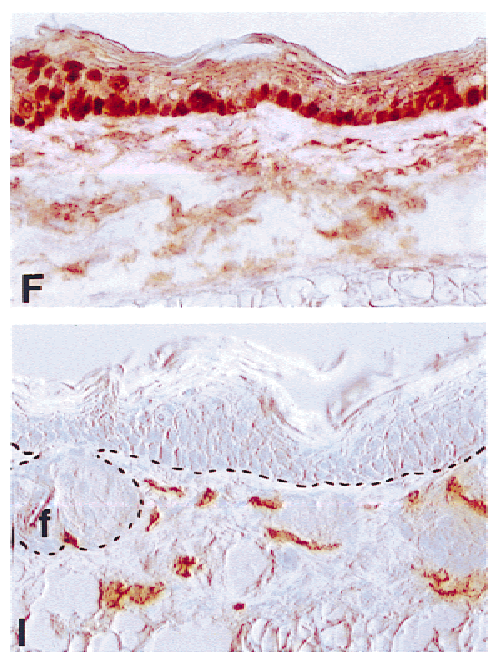

Figure 7. Mast cell deficiency abates early neoplastic progression. Presence of mast cells $(\mathrm{CAE}$, red staining; $A-C)$, proliferation of keratinocytes (Ki-67, brown staining; $D-F)$, and capillary architecture and densities (CD-31, brown staining; panels $G-I)$ were compared between wild-type littermates $\left(-\mathrm{LM}_{;} n=3 ; A, D\right.$, and $\left.G\right), \mathrm{K} 14-\mathrm{HPV} 16 \mathrm{KIT}^{+} / \mathrm{KIT}^{+}(\mathrm{n}=8 ; B, E$, and $H)$, and $\mathrm{K}_{14-\mathrm{HPV} 16} \mathrm{KIT}^{W} / \mathrm{KITW}^{W V}$ $(n=1 ; C, F$, and $I)$ mice. Ear tissue biopsies $(5 \times 2-\mathrm{mm})$ were removed from 2-month old littermates, embedded in OCT freezing medium, and sectioned $(10 \mu \mathrm{m})$. Dashed line indicates epidermal-dermal interface. Arrows point to dilated capillaries subjacent to hyperplastic skin. (f) Hair follicle. Bar, $44.6 \mu \mathrm{m}(A-I)$. 
mast cells, occurs coincident with activation of angiogenesis in a mouse model of squamous epithelial carcinogenesis and demonstrate a role for MCs in jump-starting the angiogenic switch. We show that MCs within angiogenic dysplasias are juxtaposed tightly to epithelial and subendothelial basement membranes, both of which are sites of active ECM remodeling (Coussens et al. 1996). The data support a model in which MCs contribute to premalignant progression in part by releasing two MC specific serine proteases, mMCP-6 (a tryptase), mMCP-4 (a chymase), as well as progelatinase B. MC deficiency in K14-HPV16 animals results in a severe attenuation of early neoplasia, strengthening the notion that MCs are important functionally. Thus, during the hyperplastic and dysplastic stages of squamous carcinogenesis, an ostensibly antitumor inflammatory response is hijacked, instead facilitating the angiogenic switch and the conversion of a normal dermis into an aberrant stromal support, setting the stage for subsequent progression to malignancy.

\section{Inflammation, mast cells, and angiogenesis: parameters of early neoplastic progression}

Angiogenesis in the adult organism is limited normally to conditions of tissue repair/remodeling such as exist during menstruation, mammary gland involution, wound healing, inflammation, and neoplasia (Salamonsen and Wooley 1996; Hanahan and Folkman 1996). Angiogenesis involves the activation, proliferation, and migration of endothelial cells in concert with localized proteolytic modification of the ECM (Ingber and Folkman 1989). Proteolysis of the ECM facilitates endothelial cell migration and proliferation, releasing stored angiogenic signaling molecules from sequestered latent reserves (Meininger 1995; Brown et al. 1997; Friedl et al. 1997; Poltarek et al. 1997), and loosening the stromal milieu to facilitate migration (Coussens and Werb 1996). In cutaneous organs, activation of angiogenesis and infiltration of stroma by inflammatory cells occurs within seconds following tissue injury. The implication is that skin contains regulatory machinery that can both maintain vascular quiescence, as well as initiate rapid neovascular responses. How might this be accomplished?

MCs release diverse factors known to enhance angiogenic phenotypes, including heparin, heparinase, histamine, metallo- and serine proteinases, and various polypeptide growth factors, including bFGF [ $\underline{b}$ asic (fibroblast growth factor)] and VEGF/VPF (vascular endothelial growth factor/vascular permeability factor) (Bashkin et al. 1990; Vlodavsky et al. 1992; Meininger 1995; Reed et al. 1995; Grutzkau et al. 1998). Thus, MCs provide direct mitogens for fibroblasts, endothelial, and epithelial cells, as well as diverse enzymatic activities. Activation of angiogenesis in K14-HPV16 transgenic mice was coincident with marked infiltration of dermal stroma by MCs. MCs accumulated around capillaries, as well as subjacent to epithelial basement membranes, where degranulation and release of MC products was evident. Strikingly, MCs were essentially absent within solid tumor stroma, but were prominent at tumor-host interfaces. MC exclusion from tumors reveals a distinction between the core tumor microenvironment and the microenvironments associated with premalignant progression and with cancer cell invasion into normal tissue.

A clear goal for the future is to identify the signals that recruit the MC inflammation. As the HPV-expressing skin becomes hyperkeratotic quite early, signals resulting from the loss of skin barrier function are candidates. One such effector could be activation of humoral immunity in response to consequential infections. However, when K14-HPV16 transgenic mice were treated with antibiotics or bred into Rag1/null background, they had similar spatial/temporal infiltration of dysplasias by MCs, arguing against infection as the stimulus. Instead, the signal may emanate from the incipient epidermal neoplasia itself, or perhaps arise in response to other consequential abnormalities of the affected skin.

Two neutral MC-specific serine proteolytic activities were identified in angiogenic dysplasias, mMCP-4 and mMCP-6. Mouse MCP-4, a $\beta$-chymase, is the major chymotryptic enzyme present in angiogenic dysplasias. The limited diffusability of the mMCP-4 enzyme, as demonstrated by immunolocalization, suggests that in vivo substrates are likewise located proximal to basement membranes. Indeed, our data show that mMCP-4 activates progelatinase $\mathrm{B}$, and in addition, can switch otherwise nonangiogenic tissue to the angiogenic phenotype as revealed by endothelial coculture assays for angiogenesis. We propose that mMCP-4 directly, and indirectly through its ability to activate progelatinase $\mathrm{B}$, releases sequestered angiogenic factors such as VEGF/VPF and a/bFGF from neoplastic skin, thereby effecting induction of angiogenesis. Support for the angiogenic factor sequestration/release mechanism comes from the work of Whitlock et al. (1996), who demonstrated that stromelysin-1, collagenase-3, and heparinase each degrade the ECM component perlecan resulting in release of bound bFGF. Direct evidence that gelatinase B is important for generation of angiogenic signals comes from studies of bone growth plates in gelatinase B-knockout mice, which show delayed angiogenesis (Vu et al. 1998). The identity of the angiogenic growth factor(s) released by gelatinase $\mathrm{B}$ and/or $\mathrm{mMCP}-4$ from skin ECM remains to be determined.

Our data on MCP-6 suggest that this serine protease does not affect EC growth directly, but instead activates dermal fibroblasts, thus contributing to induction of $\alpha 1$ (I) procollagen synthesis, supporting a role for tryptase in stroma generation and matrix remodeling associated with neovascularization.

Analysis of the hyperplastic stage in MC-deficient mice documents the importance of an early MC-inflammatory response. Notably, the vascular density and architecture was more characteristic of a quiescent vasculature than that observed typically underlying hyperplastic epithelium in age-matched MC-proficient HPV mice. We speculate that the impaired vascular response is caused by the absence of angiogenic growth factors (e.g., $\mathrm{bFGF}$ and VEGF/VPF) and MC-proteases delivered nor- 
mally by MCs as they focally degranulate around vascular beds and epidermal basement membranes.

\section{Generality of mast cells and neoplasia}

The presence of MCs at the borders of tumors was first reported by Westphal in 1891 (Westphal 1891). Subsequently, numerous investigators have confirmed the presence of MCs at the periphery of both experimentally induced rodent tumors (Norrby and Wooley 1993; Meininger 1995), and diverse human neoplasms (Aaltomaa et al. 1993; Shea and Prieto 1994; Duncan et al. 1998; J.M. McKerrow, V. Bhargava, E. Hansell, T. Kuwahara, M. Matley, L. Coussens, and R. Warren, in prep.); thus, MC recruitment to sites of neoplasia would appear to be HPV16-independent. Interestingly, three of the most aggressive human cancers, malignant melanoma, breast carcinoma, and colorectal adenocarcinoma, are associated commonly with a dramatic host response comprised of various inflammatory cells, especially MCs at the tumor periphery (Norrby and Wooley 1993).

Are MCs merely a smoking gun? Our analysis of neoplastic progression in a MC-deficient background, albeit one mouse, suggests that MCs are much more than passive bystanders. More likely, MCs and their products are subverted in the neoplastic tissue and functionally assist in jump-starting angiogenesis, thereby acting as key extrinsic modulators of neoplasia. Two other studies likewise support a causal role for MCs in tumorigenesis: MC-deficient $K I T^{W} / K I T^{W_{v}}$ mice were demonstrated to have decreased tumor-associated angiogenesis (Starkey et al. 1988); and, rats treated with a compound (FPL 55618) that inhibits MC degranulation, resulted in a $70 \%$ reduction in growth of mammary adenocarcinomas (Dabbous et al. 1991).

\section{Conclusion}

A primary distinction between angiogenesis associated with wound healing and that of neoplasia lies in the ability to turn off pro-angiogenic signals in the former. Following wounding, sequestered angiogenic activators can be released by degranulation of inflammatory cells and made available rapidly, thus abrogating the necessity for transcriptional induction of angiogenic growth factor genes by the wounded tissue. Turning this switch effectively 'off' could be as simple as shifting the balance between pro- and anti-inflammatory cytokines regulating infiltration and/or stability of inflammatory cells. With such programs readily available, it is not surprising that neoplastic tissues may take advantage of this machinery to initiate tissue remodeling and angiogenesis, thus providing nutrients and generating a tumor stroma for a rapidly expanding neoplastic mass. Once a tumor forms, transcription of angiogenic factors increases (Arbeit et al. 1996; Hanahan and Folkman 1996; Hanahan et al. 1996; Bergers et al. 1998). Thus, overtly malignant tissues that constitutively express high levels of angiogenic factors and ECM-degrading proteinases may no longer require the assistance of inflammatory cell-derived factors. Moreover, the presence within tumors of inflammatory cells whose mission may have been to resist (and not assist) neoplasia might also have deleterious effects, such that their exclusion could be beneficial for expansive tumor growth.

The data presented herein suggest that, in squamous carcinogenesis, angiogenic regulation is biphasic (Fig. 8). In the premalignant early phase of hyperplasia and dysplasia, infiltrating MCs degranulate and activate dermal fibroblasts. And, both directly and via activation of progelatinase $\mathrm{B}$, the MCs turn on and progressively intensify angiogenesis by releasing sequestered angiogenic activators. As neoplastic progression proceeds, angiogenic growth factor gene expression is up-regulated in the cancer cells, marking progression to the second cancer phase, wherein the tumor cells control their angiogenic phenotype directly instead of depending on the manipulation of inflammatory cells to indirectly effect neovascularization. Interestingly, invasion from solid tumors apparently again benefits from MC assistance: MCs accumulate at the leading edges of cancers in which tumor cells invade into normal tissue stroma, likely again to help convert it into a neoplastic stroma with concomitant angiogenesis.

Our study demonstrates the significance of the MC as a key accessory during the premalignant stages of squamous carcinogenesis. We show a link between MC inflammation and the angiogenic switch by a mechanism that includes the release of pro-angiogenic proteases. Thus, MC chymase can activate progelatinase B, itself a component of MC granules, as well as release angiogenic activity sequestered in the skin. MC tryptase induces normally quiescent fibroblasts to participate in formation of neoplastic stroma. The involvement of MCs and their proteases has implications for the pathogenic mechanism and potential therapeutic intervention in cutaneous malignancy, in particular for anti-angiogenic strategies aimed at arresting neoplastic progression prior to the emergence of overtly malignant tumors.

\section{Materials and methods}

\section{Transgenic mice and tissue preparation}

The K14-HPV16 transgenic mice (Arbeit et al. 1994), the characterization of neoplastic stages based on keratin intermediate filament expression, and preparation of tissue sections for histologic examination (hematoxylin and eosin) have been reported previously (Coussens et al. 1996). To identify metachromatic granules of MCs, $1 \mu \mathrm{m}$ thick sections of EPON 812-embedded skin biopsies were stained for $5 \mathrm{~min}$ in $1 \%$ toluidine blue (in water), rinsed in deionized water, dried, and mounted under cover slips in Cytoseal 60 (Stephens Scientific).

\section{Immunohistochemistry}

Tissue pieces from transgenic animals were either quick-frozen in OCT Freezing Medium (Sakura) and stored at $-80^{\circ} \mathrm{C}$ or immersion-fixed in $3.75 \%$ paraformaldehyde and phosphate-buffered saline (PBS) followed by dehydration through graded alco- 
Coussens et al.

\section{Biphasic Control of Angiogenesis During Epithelial Carcinogenesis}

A. Normal Skin

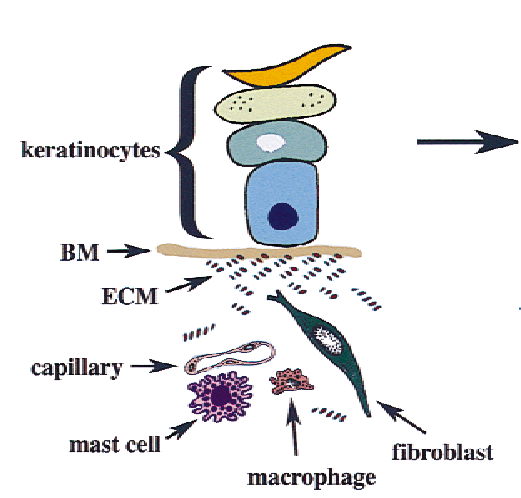

Quiescent stroma
B. Hyperplasia/Dysplasia

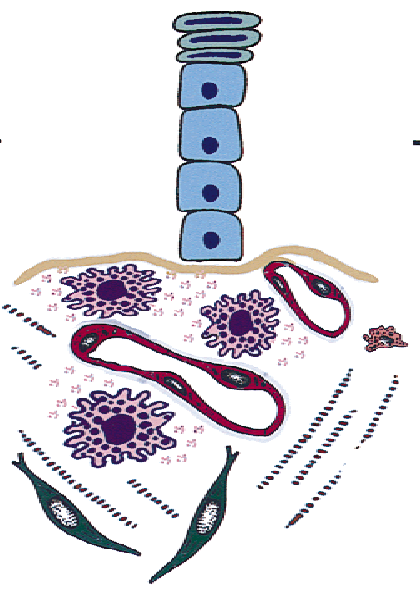

'Wound-like' stroma

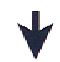

Exploitation of inflammatory

cells to release angiogenic

mediators

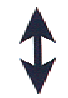

Indirect control of angiogenesis:

'The Early Phase'

\section{Squamous Carcinoma}
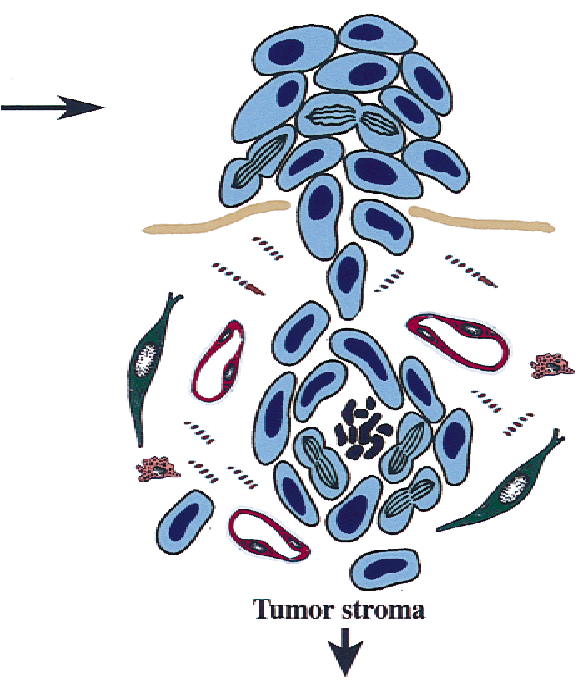

Upregulation of angiogenic growth factor genes in tumor cells

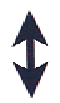

Direct control of angiogenesis: 'The Cancer Phase'

Figure 8. A model for biphasic control of angiogenesis during squamous carcinogenesis. Skin is compartmentalized into an avascular epidermis, composed of keratinocytes and dendritic cells, and a vascularized dermis composed of fibroblasts, various hemopoietic cell types, and endothelial and smooth muscle cells forming blood vessels, embedded in a quiescent stromal milieu. During premalignant progression, stroma adjacent to neoplastic epithelium resembles that observed in chronic wounds characterized by proliferating fibroblasts, increased synthesis of $\alpha 1(\mathrm{I})$ procollagen, increased vessel density, vascular permeability, increased expression and activity of ECM-degrading proteinases, increased presence of diverse leukocytes, and degranulation of MCs. MCs are exploited by neoplastic epithelia in early lesions and act to jump-start angiogenesis by their release of several bioactive molecules, e.g., bFGF, VEGF, heparin, histamine, chymase, and tryptase. Tryptase increases vascular permeability, and is a potent mitogen and activator of fibroblasts and inducer of $\alpha 1(\mathrm{I})$ procollagen synthesis. Chymase, although not a direct mitogen, induces activation of angiogenesis by releasing sequestered angiogenic activity from stromal reservoirs, through gelatinase B-dependent and independent mechanisms. Gelatinase B made by reactive stromal cells, although likely involved in ECM-remodeling, releases ECM-sequestered angiogenic activity also stimulating EC chemotaxis, proliferation, and tube formation. In contrast, maintenance of neovascularization within tumor stroma is MC-independent. Sustaining angiogenesis within the cancer phase is likely accomplished directly via dramatic up-regulation of multiple heparin-binding growth factor genes in fully malignant epithelial cells.

hols and xylene, and embedded in paraffin. OCT sections (10$\mu \mathrm{m}$ thick) were cut using a Hacker cryostat set at $-20^{\circ} \mathrm{C}$. Prior to using, cut frozen sections were dried at room temperature, followed by fixation in ice-cold acetone for $10 \mathrm{~min}$. Alternatively, 5- $\mu \mathrm{m}$-thick paraffin sections were cut using a Leica 2135 microtome. Sections were deparaffinized and subjected to immunohistochemical staining as described previously (Coussens et al. 1996). Dilution of primary antibodies was 1:200 for rabbit anti-rat MCP-1 (recognizing mMCP-4; Moredun Research Institute), 1:100 for rabbit anti-mouse gelatinase B (Behrendtsen et al. 1992), 1:100 for rat anti-mouse laminin- $\beta 1$ (Upstate Biotechnology, Inc.), 1:100 for rat anti-mouse CD31 (Pharmingen), and 1:50 for rabbit anti-mouse Ki-67 (Dianova) in blocking solution containing PBS (pH 7.4), 2.5\% goat serum and $1 \%$ bovine serum albumin (BSA). Incubation with primary antibody was $4 \mathrm{hr}$ at room temperature. Following incubation with a biotinylated secondary antibody (goat anti-rabbit IgG or goat anti-rat IgG,
1:200, Pierce Chemical) for $30 \mathrm{~min}$ at ambient temperature, antigens were revealed with either 3,3'-diaminobenzidine $(\mathrm{DAB}$; Sigma, ) or alkaline phosphatase substrate (Vector) containing Levamisole (Vector). Sections were counterstained in $1 \%$ methyl green $(1 \mathrm{~min})$, dehydrated in graded alcohols $(70 \%$, 95\%, 100\% ethanol), mounted in Cytoseal 60 (Stephens Scientific) and visualized with Nomarski optics. All immunolocalization experiments were repeated three times on multiple tissue sections and included negative controls for determination of background staining, which was negligible.

\section{Perfusion fixation and lectin binding}

For visualization of the vascular bed in situ, lectin perfusion and visualization of the bound lectin was done essentially as described previously (Tharp et al. 1985; Thurston et al. 1996). Briefly, animals were anesthetized with $50 \mathrm{mg} / \mathrm{kg}$ pentobarbital 
sodium by intraperitoneal injection and then perfused via the ascending aorta with fixative $[1 \%$ paraformaldehyde (PFA), $0.5 \%$ glutaraldehyde, in PBS at $\mathrm{pH} 7.4]$, for $5 \mathrm{~min}$ at a pressure of $130 \mathrm{mmHg}$. Fixation was followed by perfusion of (1) $50 \mathrm{ml}$ PBS (1 min); (2) $25 \mathrm{ml} \mathrm{PBS,} \mathrm{1 \%} \mathrm{BSA} \mathrm{(80} \mathrm{sec);} \mathrm{(3)} 50 \mathrm{ml} \mathrm{5- \mu g/ml}$ biotinylated Lycopersicon esculentum lectin (Vector) in PBS, $1 \%$ BSA (80 sec); (4) $25 \mathrm{ml}$ PBS, 1\% BSA (80 sec). Tissues were then removed and immersion-fixed overnight in PBS, 4\% PFA. This was followed by permeabilization in PBS, $0.3 \%$ Triton $\mathrm{X}-100$ overnight at room temperature on a rotating platform. To localize lectin binding, tissues were incubated on a rotating platform for $48 \mathrm{hr}$ with avidin-peroxidase complex (Vector) diluted 1:200, washed for $2 \mathrm{hr}$ with $50 \mathrm{~mm}$ Tris at $\mathrm{pH} 7.4,1 \%$ Triton X-100, and exposed for $10 \mathrm{~min}$ to $0.5 \mathrm{mg} / \mathrm{ml} \mathrm{DAB}$ (Sigma), $50 \mathrm{~mm}$ Tris at $\mathrm{pH} 7.4,0.01 \% \mathrm{H}_{2} \mathrm{O}_{2}$ at room temperature. After staining, tissues were washed in $\mathrm{H}_{2} \mathrm{O}$ and dehydrated through graded alcohols $(50 \%, 70 \%, 95 \%$, and $100 \%$ ethanol). Tissues were then flattened between two glass slides in $100 \%$ ethanol overnight, cleared in toluene, and mounted in Cytoseal 60 (Stephens Scientific). Whole mounts of tissues were visualized by Nomarski optics.

\section{Enzyme histochemistry}

MCs were visualized in either 10 - $\mu \mathrm{m}$ OCT-embedded acetonefixed sections, or, 5- $\mu \mathrm{m}$ paraffin-embedded tissue sections deparaffinized in xylene, hydrated through graded alcohols $100 \%$, $95 \%, 70 \%, 50 \%$ ethanol), and equilibrated in $\mathrm{H}_{2} \mathrm{O}$. Chloroacetate esterase histochemistry was performed as described previously to reveal presence of the chymotrypsin-like serine esterase activity of MCs (Leder 1979; Caughey et al. 1988). Slides were then washed extensively in water, counterstained in Gills Hematoxylin \#3 (3 sec), dehydrated in 100\% alcohol, and mounted under coverslips in $100 \%$ glycerol. Data shown are representative of results obtained following examination of tissues removed from a minimum of 10 different K14-HPV16 transgenic animals each representing a distinctive stage of neoplastic progression.

\section{RNA isolation and RT-PCR analysis}

Total cellular RNA was isolated from control tissues (auxiliary lymph node and intestine) or pieces representing distinct histologic stages removed from K14-HPV16 transgenic mice using Trizol reagent (GIBCO-BRL) according to the manufacturer's specifications and was quantified by ultraviolet absorbance at $260 \mathrm{~nm}$. Reverse transcription of total RNA (1-5 $\mu \mathrm{g}$ ) was performed with oligo(dT) primer and Superscript II RT (GIBCOBRL) according to the manufacturer's specifications. Equal volumes of cDNA were then amplified in a thermocycler (PerkinElmer/Cetus) in a final volume of $50 \mu$ l containing $50 \mathrm{~mm} \mathrm{KCl}$, $10 \mathrm{~mm}$ Tris at $\mathrm{pH} 8.3,4 \mathrm{~mm} \mathrm{MgCl}_{2}, 200 \mu \mathrm{M}$ each of all four dNTPs, $0.4 \mu \mathrm{M} 5^{\prime}$ and $3^{\prime}$ oligonucleotide primers, and 0.6 unit of Taq polymerase (Perkin-Elmer Corp.). Samples were first denatured at $95^{\circ} \mathrm{C}$ for $5 \mathrm{~min}$ and amplified for 30 cycles (1 cycle: denature at $95^{\circ} \mathrm{C} 1 \mathrm{~min}$, annealing at $55^{\circ} \mathrm{C}$ for $30 \mathrm{sec}$, and extension at $72^{\circ} \mathrm{C}$ for $1 \mathrm{~min}$ ) with a final extension of $5 \mathrm{~min}$ at $72^{\circ} \mathrm{C}$. Samples were then removed and electrophoresed on $5 \%$ polyacrylamide gels.

\section{Oligonucleotide primers}

Primers used in PCR reactions were mMCP-1 (Wastling et al. 1997) sense 5' -CAGCTGGGGACAGAATGGGG-3', antisense 5'-GAGCTCTCTGGTACTCTTTG-3' (100 bp); mMCP-2 (Xia et al. 1996) sense 5'-ACTGGCAAAATGCAGGCC-3', anti- sense 5'-CATCATCACAGACATGTG-3' (910bp); mMCP-4 (Jippo et al. 1994) sense 5'-GGAGACTCTGGAGGACCTCT-3', antisense 5'-ACAGGGAACAGTCCATCATC-3' (336 bp); mMCP-5 (McNeil et al. 1991) sense 5'-ACTCTGGAGCTTTTGCCAG-3', antisense 5'-CAGTCGACAATCTGGGTCT-3' (200 bp); mMCP-6 (Hunt et al. 1996) sense 5'-GCACATCAAAAGCCCACAGC-3' antisense 5'-TAGACAGGGGAGACAGAGGAC -3' (700 bp); mMCP-7 (Hunt et al. 1996) sense 5'-GCACTACTCCTCACTGTG-3', antisense 5'-CGCATTTTATTGAGGCATAGCAGA-3' (1003 bp).

\section{Protein extraction}

Ear and chest skin from K14-HPV transgenic and nontransgenic wild-type $\mathrm{FVB} / \mathrm{n}$ mice of various ages and stages of neoplastic progression were harvested and frozen at $-80^{\circ} \mathrm{C}$. While still frozen, samples were minced and ground under liquid $\mathrm{N}_{2}$ to a fine powder, followed by weighing and resuspension in $10 \mathrm{~mm}$ bisTris- $\mathrm{HCl}$ at $\mathrm{pH} 6.1$ (low-salt buffer) at a concentration of 10 $\mathrm{\mu l} / \mathrm{mg}$ of tissue. After vortexing for $3 \mathrm{~min}$ the suspension was centrifuged for $5 \mathrm{~min}$ at $16,000 \mathrm{~g}$. The supernatant was saved; the pellet was resuspended in the above buffer containing $2 \mathrm{M}$ $\mathrm{NaCl}$ (high-salt buffer) at $10 \mu \mathrm{l} / \mathrm{mg}$ of tissue, then vortexed and centrifuged as above. Recovered supernatants were saved for assay.

\section{Protease solution assays}

Chymase-like activity was measured by addition of 5 - $\mu$ l aliquots of samples to assay buffer containing $1 \mathrm{~mm}$ succinyl-LAla-Ala-Pro-Phe-4-nitroanilide (Sigma), $1.8 \mathrm{M} \mathrm{NaCl}$, and $9 \%$ dimethylsulfoxide in $0.45 \mathrm{M}$ Tris- $\mathrm{HCl}$ ( $\mathrm{pH} 8.0)$. Tryptase-like activity was measured by the addition of 5 - $\mu$ l aliquots of samples to assay buffer containing $0.1 \mathrm{mmole}$ tosyl-Gly-L-Pro-Lys-4-nitroanilide (Sigma) in $50 \mathrm{~mm}$ Tris- $\mathrm{HCl}$ at $\mathrm{pH} 7.6,120 \mathrm{~mm} \mathrm{NaCl}$, $30 \mu \mathrm{g} / \mathrm{ml}$ bovine lung heparin. Change in absorbance at $410 \mathrm{~nm}$ was monitored spectrophotometrically at $37^{\circ} \mathrm{C}$. Amounts of substrate cleaved were estimated using an extinction coefficient for free 4-nitroaniline of $8800 / \mathrm{M}$ per $\mathrm{cm}$.

\section{Immunoblotting}

High-salt extracts of protein samples were electrophoresed in the presence of dithiothreitol on $12.5 \%$ SDS-polyacrylamide gels, then electroblotted to polyvinylidene difluoride (PVDF) membranes, which were blocked for $30 \mathrm{~min}$ at room temperature in a solution of $0.3 \%$ Tween- 20 and $0.5 \mathrm{M} \mathrm{NaCl}$ in $50 \mathrm{~mm}$ Tris- $\mathrm{HCl}$ (pH 7.2), followed by incubation in the same buffer for $1 \mathrm{hr}$ with 1:1000 dilutions of rabbit antisera or purified rabbit antibodies. Blots were washed three times for $5 \mathrm{~min}$ with the Tris/NaCl/ Tween-20 buffer indicated above. Bound primary antibody was detected with goat anti-rabbit IgG-alkaline phosphatase antibody and Fast Red TR/Naphthol AS-MX Phosphate (Sigma). Richard Stevens (Harvard University, Cambridge, MA) provided the rabbit antiserum to $\mathrm{mMCP}-6$.

\section{Mouse MCP-4 purification}

MC chymase in the angiogenic dysplasias was purified using modifications to the methods for human skin chymase purification described by Schechter et al. (1986). Ears (840 mg total) of 6-month-old K14-HPV16 transgenic mice were extracted sequentially in low- and high-salt buffer as above. High-salt extracts were applied to a 1-ml column of SBTI-agarose (Sigma) equilibrated with high-salt buffer. The column was washed first with high-salt buffer, then with $\mathrm{H}_{2} \mathrm{O}$, until absorbance of the 
eluate at $280 \mathrm{~nm}$ reached baseline, after which $1 \mathrm{~mm} \mathrm{HCl} \mathrm{was}$ applied to the column. Eluted fractions were neutralized immediately with one-fifth volume of $0.5 \mathrm{M}$ Tris- $\mathrm{HCl}(\mathrm{pH}$ 8.0). Protein in eluted fractions was separated by SDS-PAGE and visualized by Coomassie blue staining. Protein concentration in fractions was determined using protein assay reagent (Bio-Rad) with BSA as standard. The purified chymase protein concentration was determined by using the theoretical molar extinction coefficient $33,760 / \mathrm{M}$ per $\mathrm{cm}$ at $280 \mathrm{~nm}$, computed from the deduced amino acid sequence by the method of Creighton (1984).

\section{Mouse MCP-6 purification}

Thirty-five milliliters of high-salt extracts from 5 to 6 monthold K14-HPV16 transgenic mouse ears were applied to a 4-ml $p$-aminobenzamidine-agarose column (Sigma) equilibrated in 10 mM bis-Tris- $\mathrm{HCl}$ ( $\mathrm{pH}$ 6.1) with $2 \mathrm{M} \mathrm{NaCl}$ (high-salt buffer). No tryptase-like activity was detected in the unbound fraction. The column was eluted with $150 \mathrm{~mm}$ benzamidine in high-salt buffer. The eluate was then diluted threefold with $10 \mathrm{~mm}$ bisTris- $\mathrm{HCl}(\mathrm{pH}$ 6.1) and applied to a $7.5 \times 75-\mathrm{mm}$ heparin 5PW HPLC column (Toso-Haas) equilibrated with $0.7 \mathrm{M} \mathrm{NaCl}, 10 \mathrm{~mm}$ bis-Tris- $\mathrm{HCl}(\mathrm{pH}$ 6.1). Active mMCP-6 eluted with the application of a linear gradient of $0.7 \mathrm{M} \mathrm{NaCl}$ to $2 \mathrm{M} \mathrm{NaCl}$ over $15 \mathrm{ml}$ at $1.4 \mathrm{M} \mathrm{NaCl}$. Amino acid sequencing, SDS-PAGE analysis, and immunoblotting with anti-mMCP-6 polyclonal antisera confirmed the identity and purity of the eluted activity. The purified mMCP- 6 protein concentration was determined by using the theoretical molar extinction coefficient $68,860 / \mathrm{M}$ per $\mathrm{cm}$ at $280 \mathrm{~nm}$, computed from the deduced amino acid sequence by the method of Creighton (1984).

\section{Protein sequencing}

Amino-terminal sequence analysis was performed by the Biomolecular Resource Center, University of California, San Francisco. Purified mMCP-4 and mMCP-6 (2.5- $\mu \mathrm{g}$ of proteins) were applied individually to a PVDF membrane disk and subjected to Edman degradation in a 470A gas-phase sequencer with an online 120A PTH analyzer (Applied Biosystems).

\section{Substrate zymography}

Tissue samples representing distinct histological stages of neoplastic progression, as verified by histological analysis of paraffin-embedded sections from adjacent skin, were weighed and then homogenized (1:4 weight to volume) in lysis buffer containing $50 \mathrm{~mm}$ Tris- $\mathrm{HCl}(\mathrm{pH} 8.0), 150 \mathrm{~mm} \mathrm{NaCl}, 1 \% \mathrm{NP}-40$, $0.5 \%$ deoxycholate, and $0.1 \%$ SDS. Soluble and insoluble extracts were separated by centrifugation and subsequently stored at $-20^{\circ} \mathrm{C}$. Equivalent amounts of soluble extract were analyzed by gelatin zymography (Herron et al. 1986a,b) on 10\% SDSpolyacrylamide gels copolymerized with substrate $11 \mathrm{mg} / \mathrm{ml}$ of gelatin) in sample buffer (10\% SDS, $0.25 \mathrm{M}$ Tris-HCl, and $0.1 \%$ bromophenol blue at $\mathrm{pH}$ 6.8). After electrophoresis, gels were washed twice for $15 \mathrm{~min}$ in $2.5 \%$ Triton X-100, incubated for 16 hr at $37^{\circ} \mathrm{C}$ in $50 \mathrm{~mm}$ Tris- $\mathrm{HCl}, 10 \mathrm{~mm} \mathrm{CaCl}_{2}(\mathrm{pH} 7.6)$, and then stained in $0.5 \%$ Coomassie blue and destained in $50 \%$ methanol. Negative staining indicates the location of active protease bands. Exposure of proenzymes within tissue extracts to SDS during gel separation procedures leads to activation without proteolytic cleavage (Talhouk et al. 1991). For inhibition of proteolytic activities, substrate gels were incubated in substrate buffer with either $4 \mathrm{~mm}$ 1,10-phenanthroline (Sigma), $5 \mathrm{~mm}$ PMSF (Sigma), or $10 \mu \mathrm{g} / \mathrm{ml}$ recombinant ecotin (McGrath et al. 1991; provided by Charles Craik, University of California, San
Francisco) as described (Adler et al. 1990). Data shown are representative of results obtained following examination of 91 tissue pieces representing various stages of neoplastic progression in K14-HPV16 transgenic mice.

\section{Cell culture}

PMDFs were isolated from $\mathrm{FVB} / \mathrm{n}$ mice by the method of BossyWetzel et al. (1992) and maintained in culture at subconfluence in DMEM containing 4.5 grams/liter glucose, and supplemented with $10 \%$ fetal bovine serum (GIBCO-BRL), $50 \mathrm{U} / \mathrm{ml}$ penicillin, $50 \mu \mathrm{g} / \mathrm{ml}$ streptomycin, at $37^{\circ} \mathrm{C}$ in $5 \% \mathrm{CO}_{2}$. HUVECs (Clonetics) were maintained in EBM complete medium (Clonetics) supplemented with 5\% fetal calf serum. BCEs were a gift from the laboratory of Judah Folkman (Harvard University, Boston, MA), and were maintained in DMEM containing $10 \%$ heat-inactivated calf serum.

\section{DNA synthesis assay}

Stimulation of DNA synthesis in subconfluent cultures of PMDFs or HUVECs was determined by radiolabeled thymidine incorporation. Cells were plated at 2500 cells $/ \mathrm{cm}^{2}$ in multiwell plates containing growth medium supplemented with fetal calf serum [PMDFs, $10 \%$; HUVECs, $5 \%$ (GIBCO-BRL)]; prior to plating HUVECs, culture dishes were precoated with $1.5 \%$ gelatin in PBS. After $24 \mathrm{hr}$, cells were washed three times with PBS and covered with serum-free DMEM (GIBCO-BRL) containing $0.5 \%$ bovine serum albumin (GIBCO-BRL). After an additional $24 \mathrm{hr}$, cells were incubated for $16 \mathrm{hr}$ with agonists [murine bFGF, 1 and $10 \mathrm{ng} / \mathrm{ml}$, (GIBCO-BRL); human VEGF at 1 and $10 \mathrm{ng} / \mathrm{ml}$ (Sigma); purified mMCP-4, 2 and $20 \mathrm{~nm}$ in $50 \mathrm{~mm}$ Tris- $\mathrm{HCl}$ at $\mathrm{pH}$ 8.0; purified mMCP-6, 1 and $10 \mathrm{~nm}$ in $10 \mathrm{~mm}$ bis-Tris at $\mathrm{pH}$ $6.1,0.7 \mathrm{M} \mathrm{NaCl}, 225 \mu \mathrm{g} / \mathrm{ml}$ heparin (Sigma); heparin at 74 and $740 \mathrm{ng} / \mathrm{ml}$ ], followed by the addition of [methyl- ${ }^{3} \mathrm{H}$ ] thymidine $(2 \mathrm{mCi} / \mathrm{ml}, \mathrm{NEN})$ for an additional $6 \mathrm{hr}$. Trichloroacetic acidprecipitable material was solubilized in $0.3 \mathrm{~N} \mathrm{NaOH}$, and liquid scintillation counting assessed the incorporated radioactivity. Each assay condition was in triplicate; results shown are representative from two independent experiments.

\section{In situ hybridization}

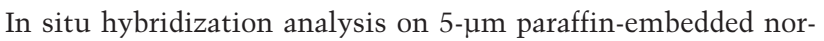
mal and transgenic skin was carried out as described previously (Coussens et al. 1996). The riboprobe used to detect $\alpha 1$ (I) collagen (pmCol1-129) mRNA was provided by Paul Bornstein (University of Washington, Seattle, WA).

\section{Endothelial tube formation assay}

BCEs were trypsinized and resuspended in DMEM with 10\% calf serum. Cells $\left(4 \times 10^{5} / \mathrm{ml}\right)$ were mixed $1: 1$ with a chilled collagen solution (Vitrogen 100; Collagen Corp.) in MEM medium containing $0.1 \% \mathrm{NaHCO}_{3}, 2 \mathrm{~mm}$ glutamine, and $10 \mathrm{~mm}$ HEPES. Skin biopsies were removed from 1-month-old transgenic mice, washed in PBS, and cut into $<1 \mathrm{~mm}^{2}$ pieces and then incubated for $24 \mathrm{hr}$ at $37^{\circ} \mathrm{C}$ in $5 \% \mathrm{CO}_{2}$ balanced air incubator in DMEM containing $0.5 \%$ BSA and either $10 \mathrm{~mm}$ mMCP-6, 20 mM mMCP-4, $1 \mathrm{ng} /$ hl gelatinase B (Calbiochem), or medium/ BSA alone. After $24 \mathrm{hr}$, medium was removed and fresh medium containing appropriate agonist was replaced and allowed to incubate for an additional $24 \mathrm{hr}$. Aliquots $(250 \mu \mathrm{l})$ of the collagencell mixture were pipetted into 48-well tissue culture plates, and skin pieces were added to each well before the solution was allowed to gel at $37^{\circ} \mathrm{C}$. Culture plates were incubated in $10 \%$ 
$\mathrm{CO}_{2}$ balanced air atmosphere and observed for endothelial cell growth, migration, and tube formation over a period of 2 weeks. In addition, $10 \mathrm{~mm} \mathrm{mMCP}-6,20 \mathrm{~mm} \mathrm{mMCP}-4$, and $1 \mathrm{ng} / \mu \mathrm{l}$ gelatinase $\mathrm{B}$ (Calbiochem) were added individually to collagenEC mixtures, and monitored for tube formation over a 1-week period.

\section{$K I T^{W} / K I T^{W_{V}}$ genotyping}

WB/ReJ $K I T^{W} /+$ and C57BL/6J-KIT $T^{W_{V}} /+$ mice (Jackson Laboratories) were each intercrossed into the $\mathrm{FVB} / \mathrm{n}$ strain four generations. Genotypes were determined from tail DNA by a PCRbased assay (Laig-Webster et al. 1998). Briefly, to trace the KIT ${ }^{W}$ mutation, oligonucleotide primers specific for intron 9 (5'CCAAGAGAAAGCTTTGTTCCCTGAATGTGC-3') and intron 10 (5'-AGAACAATTCAATGCTCAT-3') from the mouse c-KIT gene (Hayashi et al. 1991; Gokkel et al. 1992) were generated. To trace the $K I T^{W_{V}}$ mutation, oligonucleotide primers specific for exon 12 (5'-CATTGGGAGCTGGTGCCTTCGGGAAGGT-3') and exon 13 (5'-AGACTACCTCCCACCA-3') from the mouse $c$-KIT gene (Gokkel et al. 1992) were generated. Utilizing these primers, mutant alleles, but not wild-type alleles, were amplified preferentially in 50- $\mu 1$ reactions containing 3 $\mu \mathrm{l}$ of genomic tail DNA (100 ng), 2.5 units of AmpliTaq Gold (Perkin-Elmer), 10 pmoles of each oligonucleotide primer, 200 $\mu \mathrm{M}$ dNTPs and $1.5 \mathrm{mM} \mathrm{MgCl}_{2}$. KIT ${ }^{W}$ and $K I T^{W_{V}}$ mutations were detected by PCR amplification $\left(K I T^{W}: 1\right.$ cycle at $94^{\circ} \mathrm{C}$ for $5 \mathrm{~min}$, 20 cycles at $94^{\circ} \mathrm{C}$ for $30 \mathrm{sec}$ and $72^{\circ} \mathrm{C}$ for $1 \mathrm{~min}, 40$ cycles at $94^{\circ} \mathrm{C}$ for $30 \mathrm{sec}, 58^{\circ} \mathrm{C}$ for $1 \mathrm{~min}$ and $72^{\circ} \mathrm{C}$ for $30 \mathrm{sec} K I T^{W v}: 1$ cycle at $94^{\circ} \mathrm{C}$ for $5 \mathrm{~min}, 10$ cycles at $94^{\circ} \mathrm{C}$ for $30 \mathrm{sec}$ and $72^{\circ} \mathrm{C}$ for $1 \mathrm{~min}, 50$ cycles at $94^{\circ} \mathrm{C}$ for $30 \mathrm{sec}, 51^{\circ} \mathrm{C}$ for $1 \mathrm{~min}$, and $72^{\circ} \mathrm{C}$ for $30 \mathrm{sec}$. PCR products were visualized with ultraviolet light on $2 \%$ agarose gels stained with ethidium bromide. $K I T^{W} / K I T^{W_{V}}$ genotypes were confirmed by DNA sequence analysis.

\section{Acknowledgments}

We thank Donald McDonald, Gavin Thurston, and Tom Murphy for assistance with lectin perfusions and whole mount microscopy, Richard Stevens for rabbit anti-mMCP-6 IgG, Paul Bornstein for type I collagen cDNA, Charles Craik and Sushma Selvarajan for recombinant ecotin, John Blount for genotype analysis, and Emily Bergsland, Jeffrey Hager, and Dylan Daniel for valuable discussion. This study was supported by grants from the National Institutes of Health (HL24136, G.H.C; CA72006, Z.W.), by grants from the National Cancer Institure (D.H.), the American Social Health Association/Pfizer Fellowship in Sexually Transmitted Diseases (L.M.C.), and a Howard Hughes Medical Institute Transgenic Animal Research Grant (G.H.C.)

The publication costs of this article were defrayed in part by payment of page charges. This article must therefore be hereby marked 'advertisement' in accordance with 18 USC section 1734 solely to indicate this fact.

\section{References}

Aaltomaa, S., P. Lipponen, S. Papinaho, and V-M. Kosma. 1993. Mast cells in breast cancer. Anticancer Res. 13: 785-788.

Adler, R.R., C.A. Brenner, and Z. Werb. 1990. Expression of extracellular matrix-degrading metalloproteinases and metalloproteinase inhibitors is developmentally regulated during endoderm differentiation of embryonal carcinoma cells. Development 110: 211-220.
Arbeit, J., K. Munger, P. Howley, and D. Hanahan. 1994. Progressive squamous epithelial neoplasia in K14-human papillomavirus type 16 transgenic mice. J. Virol. 68: 358-368.

Arbeit, J.M., D. Olson, and D. Hanahan. 1996. Upregulation of fibroblast growth factors and their receptors during multistage epidermal carcinogenesis in K14-HPV16 transgenic mice. Oncogene 13: 1847-1857.

Bashkin, P., E. Razin, A. Eldor, and I. Vlodavsky. 1990. Degranulating mast cells secrete an endoglycosidase which degrades heparin sulfate in subendothelial extracellular matrix. Blood 75: 2204-32212.

Befus, A.D., F.L. Pearce, J. Gauldie, P. Horsewood, and J. Bienenstock. 1982. Mucosal mast cells: Isolation and functional characteristics of rat intestinal mast cells. J. Immunol. 128: $2475-2486$.

Behrendtsen, O., C.M. Alexander, and Z. Werb. 1992. Metalloproteinases mediate extracellular matrix degradation by cells from mouse blastocyst outgrowths. Development 114: 447-456.

Bergers, G., D. Hanahan, and L.M. Coussens. 1998. Angiogenesis and apoptosis are cellular parameters of neoplastic progression in transgenic mouse models of tumorigenesis. Int. J. Dev. Biol. 42: 995-1002.

Bernstein, A., B. Chabot, P. Durbreuil, A. Reith, K. Mocka, S. Majumder, P. Rat, and P. Bessmer. 1990. The mouse W/c-KIT locus. Ciba Found. Symp. 148: 148-166.

Blair, R.J., H. Meng, M.J. Marchese, S. Ren, L.B. Schwartz, M.G. Tonnesen, and B.L. Gruber. 1997. Human mast cells stimulate vascular tube formation. J. Clin. Invest. 99:2691-2700.

Bossy-Wetzel, E., R. Bravo, and D. Hanahan. 1992. Transcription factors JunB and $c$-Jun are selectively up-regulated and functionally implicated in fibrosarcoma development. Genes \& Dev. 6: 2340-2351.

Brown, L., M. Detmar, K. Claffey, J. Nagy, D. Feng, A. Dvorak, and H. Dvorak. 1997 Vascular permeability factor/vascular endothelial growth factor. A multifunctional angiogenic cytokine. In Regulation of angiogenesis. (ed. I. Goldberg and E. Rosen). pp. 233-269. Birkhauser Verlag, Basel, Switzerland.

Cairns, J.A. and A.F. Wells. 1997. Mast cell tryptase stimulates the synthesis of type I collagen in human lung fibroblasts. J. Clin. Invest. 99: 1313-1321.

Caughey, G.H. 1995. Mast cell chymases and tryptases: Phylogeny, family relations, and biogenesis. In Mast cell proteases in immunology and biology (ed. G.H. Caughey), pp. 305329. Marcel Dekker, New York, NY.

Caughey, G.H., N.F. Viro, L.D. Calonico, D.M. McDonald, S.C. Lazarus, and W.M. Gold. 1988. Chymase and tryptase in dog mastocytoma cells: Asynchronous expression as revealed by enzyme cytochemical staining. I. Histochem. Cytochem. 36: 1053-1060.

Caughey, G.H., W.W. Raymond, E. Bacci, R.J. Lombardy, and R.R. Tidwell. 1993. Bis(5-amidino-2-benzimidazolyl)methane and related amidines are potent, reversible inhibitors of mast cell tryptases. J. Pharmacol. Exp. Ther. 264: 676-682.

Chabot, B., D.A. Stephenson, V.M. Chapman, P. Besmer, and A. Bernstein. 1988. The proto-oncogene c-kit encoding a transmembrane tyrosine kinase receptor maps to the mouse $\mathrm{W}$ locus. Nature 335: 88-89.

Christofori, G. and D. Hanahan. 1994. Molecular dissection of multi-stage tumorigenesis in transgenic mice. In Seminars in cancer biology (ed. Glenn Merlino). pp 3-12. Academic Press, London, UK.

Coussens L.M. and Z. Werb. 1996. Matrix metalloproteinases and the development of cancer. Chem. Biol. 3: 895-904.

Coussens, L.M., D. Hanahan, and J.M. Arbeit. 1996. Genetic predisposition and parameters of malignant progression in 
K14-HPV16 transgenic mice. Am. J. Pathol. 149: 1899-1917.

Creighton, T.F. 1984. Chemical properties of polypeptides. In Proteins, structures and molecular properties, p. 14. W.H. Freeman and Company, New York, NY.

Dabbous, M.K., R. Walker, L. Haney, L.M. Carter, G.L. Nicolson, and D.E. Wooley. 1986. Mast cells and matrix degradation at sites of tumor invasion in rat mammary adenocarcinomas. Br. J. Cancer 54: 459-465.

Dabbous, M.K., L. Laney, G.L. Nicolson, D. Eckley, and D.E. Wooley. 1991. Mast cell modulation of tumor cell proliferation in rat mammary adenocarcinoma $13762 \mathrm{NF}$. Br. J. Cancer 63: 873-878.

DeLisser, H.M., P.J. Newman, and S.M. Albelda. 1994. Molecular and functional aspects of PECAM-1/CD-31. Immunol. Today 15: 490-495.

Detmar, M. 1996. Molecular regulation of angiogenesis in the skin. J. Invest. Derm. 149: 1899-1917.

Duncan L.M., L.A. Richards, and M.C. Mihm. 1998. Increased mast cell density in invasive melanoma. J. Cutan. Pathol. 25: 11-15.

Dvorak, H.F. 1986. Tumors: Wounds that do not heal. New Engl. J. Med. 315: 1650-1659.

Eady, R.A.J., T. Cowen, T.F. Marshall, V. Plummer, and M.W. Greaves. 1979. Mast cell population density, blood vessel density and histamine content in normal skin. Br. J. Dermatol. 100: 635-640.

Fang, K., W.W. Raymond, S.C. Lazarus, and G.H. Caughey. 1996. Dog mastocytoma cells secrete a 92-kD gelatinase activated extracellularly by mast cell chymase. J. Clin. Invest. 97: 1589-1596.

Fang, K., W.W. Raymond, J. Blount, and G.H. Caughey. 1997. Dog mast cell $\alpha$-chymase activates progelatinase B by cleaving the Phe88-Gln89 and Phe91-Glu92 bonds of the catalytic domain. J. Biol. Chem. 272: 25628-25635.

Fearon, E.R. and B. Vogelstein. 1990. A genetic model for colorectal tumorigenesis. Cell 61: 759-767.

Folkman, J. 1990. What is the evidence that tumors are angiogenesis dependent? I. Nat1. Cancer Inst. 82: 4-6.

Folkman, J. and D. Hanahan. 1991. Expression of the angiogenic phenotype during development of murine and human cancer. In Origins of human cancer: A comprehensive review (ed. J. Brugge, J. Curran, E. Harlow, and F. McCormick), pp. 803-814. Cold Spring Harbor Laboratory Press, Cold Spring Harbor, NY.

Friedl, A., Z. Chang, A. Tierney, and A.C. Rapraeger. 1997. Differential binding of fibroblast growth factor- 2 and -7 to basement membrane heparin sulfate. Am. J. Pathol. 150: 14431455.

Ghildyal, N., D.S. Friend, R.L. Stevens, K.F. Austen, C. Huang, J.F. Penrose, Sali, and M.F. Gurush. 1996. Fate of two mast cell tryptases in V3 mastocytosis and normal BALB/c mice undergoing passive systemic anaphylaxis: Prolonged retention of exocytosed mMCP-6 in connective tissue, and rapid accumulation of enzymatically active $\mathrm{mMCP}-7$ in the blood. J. Exp. Med. 184: 1061-1073.

Gokkel, E., Z. Grossman, B. Ramot, Y. Yarden, G. Rechavi, and D. Givol. 1992. Structural organization of the murine c-kit proto-oncogene. Oncogene 7: 1423-1429.

Gregoire, M. and B. Lieubeau. 1995. The role of fibroblasts in tumor behavior. Cancer Metast. Rev. 14: 339-350.

Gruber, B.L., R.R. Kew, A. Jelaska, M.J. Marchese, J. Garlick, S. Ren, L.B. Schwartz, and J.H. Korn. 1997. Human mast cells activate fibroblasts. J. Immunol. 158: 2310-2317.

Grutzkau, G.A., S. Kruger-Krasagakes, H. Baumeister, C. Schwartz, H. Kogel, P. Welker, U. Lippert, B.M. Henz, and A. Moller. 1998. Synthesis, storage, and release of vascular en- dothelial growth factor/vascular permeability factor (VEGF/ VPF) by human mast cells: Implications for the biological significance of VEGF206. Mol. Biol. Cell 9: 875-884.

Hanahan, D. 1998. A flanking attack on cancer. Nat. Med. 4: $1-2$.

Hanahan, D. and J. Folkman. 1996. Patterns and emerging mechanisms of the angiogenic switch during tumorigenesis. Cell 86: 353-364.

Hanahan, D., G. Christofori, P. Naik, and J. Arbeit. 1996. Transgenic mouse models of tumor angiogenesis: the angiogenic switch, its molecular controls, and prospects for preclinical therapeutic models. Eur. J. Cancer 32: 2386-2393.

Hartmann, T., S.J. Ruoss, W.W. Raymond, K. Seuwen, and G.H. Caughey. 1992. Human tryptase as a potent, cell-specific mitogen: role of signaling pathways in synergistic responses. Am. J. Physiol. 262: 528-534.

Hayashi, S., T. Kunisada, M. Ogawa, K. Yamaguchi, and S. Nishikawa. 1991. Exon skipping by mutation of an authentic splice site of c-kit gene in W/W mouse. Nucleic Acids Res. 19: $1267-1271$.

Herron, G.S., Z. Werb, K. Dwyer, and M.J. Banda. 1986a. Secretion of metalloproteinases by stimulated capillary endothelial cells. I. Production of procollagenases and prostromelysin exceeds expression of proteolytic activity. J. Biol. Chem. 261: $2810-2813$

Herron, G.S., M.J. Banda, E.J. Clark, J. Gavrilovic, and Z. Werb. 1986b. Secretion of metalloproteinases by stimulated capillary endothelial cells. II. Expression of collagenase and stromelysin activities is regulated by endogenous inhibitors. J. Biol. Chem. 261: 2814-2818.

Huang, R., T. Blom, and L. Hellman. 1991. Cloning and structural analysis of MMCP-1, MMCP-4 and MMCP-5, three mouse mast cell-specific serine proteases. Eur. J. Immunol. 21: 1611-1621.

Hunt, J.E., R. Stevens, K. Austen, J. Zhang, Z. Xia, and N. Ghildyal. 1996. Natural distribution of the mouse mast cell protease 7 gene in the C57BL/6 mouse. I. Biol Chem. 271: 2851-2855.

Ingber, D.E. and J. Folkman. 1989. How does extracellular matrix control capillary morphogenesis? Cell 58: 803-805.

Jippo, T., H. Ushio, S. Hirota, H. Mizuno, A. Yamatodani, S. Nomura, H. Matsuda, and Y. Kitamura. 1994. Poor response of cultured mast cells derived from $\mathrm{mi} / \mathrm{mi}$ mutant mice to nerve growth factor. Blood 84: 2977-2983.

Kinzler, K.W. and B. Vogelstein. 1998. Landscaping the cancer terrain. Science 280: 1036-1037.

Kitamura, Y., S. Go, and K. Hatanaka. 1978. Decrease of mast cells in $W / W^{v}$ mice and their increase by bone marrow transplantation. Blood 52: 447-452.

Laig-Webster, M., L.M. Coussens, D. Hanahan, and G. Caughey. 1998. A general method for genotyping mast cell-deficient $K I T^{W} / K I T^{W-v}$ mice by allele-specific polymerase chain reaction. FASEB J. 12: A895.

Leder, L.D. 1979. The chloroacetate esterase reaction. A useful means of histological diagnosis of hematological disorders from paraffin sections of skin. Am. J. Dermatopath. 1: 39-42.

McGrath, M.E., W.M. Hines, J.A. Sakanari, R.J. Fletterick, and C.S. Craik. 1991. The sequence and reactive site of ecotin. A general inhibitor of pancreatic serine proteases from Escherichia coli. J. Biol. Chem. 266: 6620-6625.

McNeil, H., K. Austen, L. Someville, M. Gurish, and R. Stevens. 1991. Molecular cloning of the mouse mast cell protease-5 gene. J. Biol. Chem. 266: 20316-20322.

Meininger, C. 1995. Mast cells and tumor-associated angiogenesis. In Human basophils and mast cells: Clinical aspects. (ed. G. Marone), pp. 238-256. Karger, Basel, Switzerland. 
Molino, M., E.S. Barnatham, R. Numerof, J. Clark, M. Dreyer, A. Cumashi, J.A.Hoxie, N. Schechter, M. Woolkalis, and L.F. Brass. 1997. Interactions of mast cell tryptase with thrombin receptors and PAR-2. J. Biol. Chem. 272: 4043-4049.

Mombaerts, P., J. Iacomini, R.S. Johnson, K. Herrup, S. Tonegawa, and V.E. Papaioannou. 1992. RAG-1 deficient mice have no mature B and T lymphocytes. Cell 68: 869-877.

Nocka, K., J.C. Tan, E. Chiu, T.Y. Chu, P. Ray, P. Traktman, and P. Bessmer. 1990. Molecular basis of dominant negative and loss of function mutations at the murine c-kit/white spotting locus: $W 37, W^{v}, W 41$, and $W . E M B O ~ J .9: 1805-1813$.

Norrby, K. and D.E. Wooley. 1993. Role of mast cells in mitogenesis and angiogenesis in normal tissue and tumor tissue. Adv. Biosci. 89: 71-115.

Ohtani, H. 1998. Stromal reaction in cancer tissue: Pathophysiologic significance of the expression of matrix-degrading enzymes in relation to matrix turnover and immune/inflammatory reactions. Pathol. Int. 48: 1-9.

Poltarek, Z., T. Cohen, R. Sivan, Y. Kandelis, G. Spira, I. Vlodovsky, E. Keshet, and G. Neufeld. 1997. VEGF 145 , a secreted vascular endothelial growth factor isoform that binds to extracellular matrix. J. Biol. Chem. 272: 7151-7158.

Reed, J.A., A.P. Albino, and N.S. McNutt. 1995. Human cutaneous mast cells express basic fibroblast growth factor. $L a b$. Invest. 72: 215-222.

Reynolds, D.S., R.L. Stevens, W.S. Lane, M.H. Carr, K.F. Austen, and W.E. Serafin. 1990. Different mouse mast cell populations express various combinations of at least six distinct mast cell serine proteases. Proc. Natl. Acad. Sci. 87: 32303234.

Reynolds, D.S., D.S. Gurley, K.F. Austen, and W.E. Serafin. 1991. Cloning of the cDNA and gene of mouse mast cell protease- 6 . Transcription by progenitor mast cells and mast cells of the connective tissue subclass. I. Biol. Chem. 266: $3847-3853$.

Roitt, I.M., J. Brostoff, and D.K. Male, eds. 1989. Cells involved in the immune response. In Immunology, pp. 11-28. Gower, London, UK.

Salamonsen, L. and D.E. Wooley. 1996. Matrix metalloproteinases in normal menstruation. Hum. Reprod. 11: 124-133.

Schechter, N.M., J.K. Choi, D.A. Slavin, D.T. Deresienski, S. Sayama, G. Dong, R.M. Lavker, D. Proud, and G.S. Lazarus. 1986. Identification of a chymotrypsin-like proteinase in human mast cells. J. Immunol. 137: 962-970.

Schechter, N.M., L.F. Brass, R.M. Lavker, and P.J. Jensen. 1998 Reaction of mast cell protease tryptase and chymase with protease activated receptors (PARs) on keratinocytes and fibroblasts. J. Cell. Physiol. 176: 365-373.

Shea, C.R. and V.G. Prieto. 1994. Mast cells in angiolipomas and hemangiomas of human skin: Are they important for angiogenesis? J. Cutan. Pathol. 21: 247-251.

Smith-McCune, K. and N. Weidner. 1994. Demonstration and characterization of the angiogenic properties of cervical dysplasia. Cancer Res. 54: 800-804.

Smith-McCune, K., Y-H. Zhu, D. Hanahan, and J. Arbeit. 1997. Cross-species comparison of angiogenesis during the premalignant stages of squamous carcinogenesis in the human cervix and K14-HPV16 transgenic mice. Cancer Res. 57: 12941300.

Starkey, JR., P.K. Crowle, and S. Taubenberger. 1988. Mast-cell deficient $W / W^{v}$ mice exhibit a decreased rate of tumor angiogenesis. Int. J. Cancer 42: 48-52.

Stevens, R.L., D.S. Friend, H.P. McNeil, V. Schiller, N. Ghildyal, and K.F. Austen. 1994. Strain-specific and tissuespecific expression of mouse mast cell secretory granule proteases. Proc. Nat1. Acad. Sci. 91: 128-132.
Talhouk, R.S., J.R. Chin, E.N. Unemori, Z. Werb, and M.J. Bissell. 1991. Proteinases of the mammary gland: Developmental regulation in vivo and vectorial secretion in culture. $D e-$ velopment 112: 439-449.

Tharp, M.D., L.L. Seelig, R.E. Tigelaar, and P.R. Bergstresser. 1985. Conjugated avidin binds to mast cell granules. J. Histochem. Cytochem. 33: 27-32.

Thurston, G., P. Baluk, A. Hirata, and D. McDonald. 1996. Permeability-related changes revealed at endothelial cell borders in inflamed venules by lectin binding. Am. J. Physiol. 271: 2547-2562.

Vlodavsky, I., A. Eldor, A. Haimovitz-Friedman, Y. Matzner, R. Ishai-Michaeli, O. Lider, T. Naparstek, I.R. Cohen, and Z. Fuks. 1992. Expression of heparanase by platelets and circulating cells of the immune system: Possible involvement in diapedesis and extravasation. Inv. Metast. 12: 112-127.

Vu, T.V., J.M. Shipley, G. Bergers, J. Berger, J.A. Helms, D. Hanahan, S.D. Shapiro, R. Senior, and Z. Werb. 1998. Matrix metalloproteinase gelatinase B is a key regulator of growth plate angiogenesis and apoptosis of hypertrophic chondrocytes. Cell 93: 411-422.

Vuorio, E. and B. de Crombrugghe. 1990. The family of collagen genes. Annu Rev. Biochem. 59: 837-872.

Wastling, J., C. Scudamore, E. Thornton, G. Newlands, and H. Miller. 1997. Constitutive expression of mouse mast cell protease-1 in normal BALB/c mice and its up-regulation during intestinal nematode infection. Immunology 90:308313.

Wernert, N. 1997. The multiple roles of tumor stroma. Virchows Arch. 430: 433-443.

Westphal, E. 1891. Uber mastzellen. In Farbenanalytische Ut ersuchuugen zur Histologie und Klinik des Blutes: gesammelte Mitt(h)eilungen (ed. P. Ehrlich), Vol. 1, p. 17. Hirschwald Press, Berlin, Germany.

Whitlock, J.M., A.D. Murdoch, R.V. Iozzo, and P.A. Underwood. 1996. The degradation of human endothelial cell-derived perlecan and release of bound basic fibroblast growth factor by stromelysin, collagenase, plasmin, and heparanases. $J$. Biol. Chem. 271: 10079-10086.

Xia, Z., N. Ghildyal, K.F. Austen, and R.L. Stevens. 1996. Posttranscriptional regulation of chymase expression in mast cells. J. Biol. Chem. 271: 8747-8753.

Yong, L.C. 1997. The mast cell: Origin, morphology, distribution, and function. Exp. Toxicol. Pathol. 49: 409-424. 


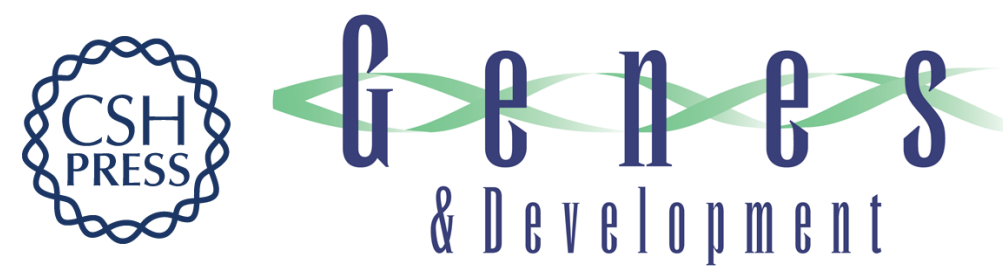

\section{Inflammatory mast cells up-regulate angiogenesis during squamous epithelial carcinogenesis}

Lisa M. Coussens, Wilfred W. Raymond, Gabriele Bergers, et al.

Genes Dev. 1999, 13:

\section{References This article cites 77 articles, 30 of which can be accessed free at: http://genesdev.cshlp.org/content/13/11/1382.full.html\#ref-list-1}

\section{License}

Email Alerting
Service

Receive free email alerts when new articles cite this article - sign up in the box at the top right corner of the article or click here.

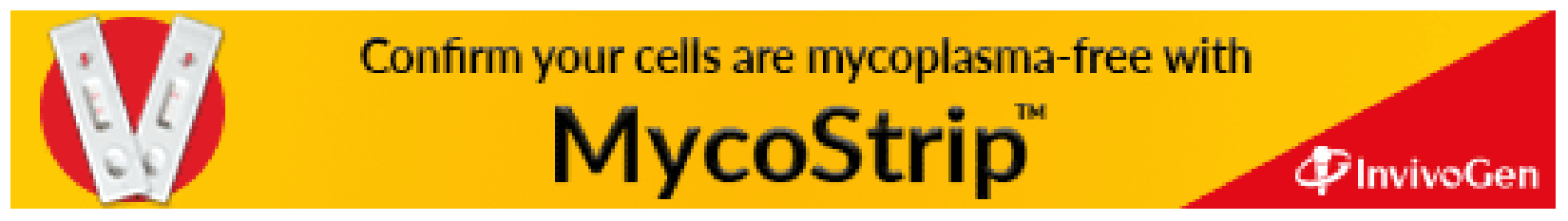

